Article

\title{
Assessing the Greenness of Enterprise Resource Planning Systems through Green IT Solutions: A Romanian Perspective
}

\author{
Minodora Ursacescu *, Dan Popescu, Cristina State and Ion Smeureanu \\ Faculty of Management, Bucharest University of Economic Studies, 6 Romana Square, \\ Bucharest 010374, Romania \\ * Correspondence: minodora.ursacescu@man.ase.ro
}

Received: 17 June 2019; Accepted: 16 August 2019; Published: 18 August 2019

check for updates

\begin{abstract}
Businesses and technology play an important role in the global economy, where the achievement of sustainability goals has a positive impact on society and companies. In this regard, there is a need to integrate information technology and sustainability to enable companies to act in a greener manner. Knowing that the Enterprise Resource Planning (ERP) system is one of the most powerful business solutions for companies, it is crucial to align its use with sustainability elements through the use of green information technology (IT). We explored the relationship between ERP systems and green IT practices to assess how green IT provides an opportunity for organizations to improve ERP systems in more environmentally responsible initiatives. For that purpose, we empirically analyzed four Romanian economic sectors based on an online survey that contained criteria to explore organizational awareness about developing green ERP systems. The findings indicate that companies are generally focused on the key benefits of ERP systems related to operational aspects and less on the sustainability benefits. Based on these results, the main conclusion highlights the strong need to embed IT in business sustainability initiatives by adopting green IT solutions.
\end{abstract}

Keywords: sustainability; ERP system; green IT; green ERP system; virtualization; asset lifecycle

\section{Introduction}

The global economy places companies in a new dynamic evolution that is highlighted by the three pillars of social, economic, and sustainable development [1,2]. According to the systemic approach to these pillars, companies' responsibilities exceed the traditional goal of making a profit [3], thus encouraging them to engage in sustainable development initiatives. The resources produced by healthy and long-term growth are found in the innovation capabilities that are supported by information and communication technology (ICT) [4-6]. Every company should consider the impact of the use of ICT on the environment and take care to adopt solutions to minimize negative effects [7,8]. From this perspective, a new paradigm in business sustainability solutions [9] and organization management was revealed. This suggests that there is a need to integrate eco-responsible practices when using information technology (IT) to ensure that all the software solutions that an organization applies are environmentally friendly $[10,11]$. IT hardware has created environmental problems related to its production and disposal. Computer, networking, and telecommunication technologies consume electricity, raw materials, and chemicals that generate greenhouse gas (GHG) emissions and impact the environment [12-16]. Given these circumstances, there is an increasing need for organizations to minimize the environmental impact of IT to help create a more sustainable environment [17].

IT is expected to play a lead role in achieving the goals of sustainable business, through measures that improve energy efficiency and reduce the carbon footprint. In this regard, the green potential of 
IT should be increased $[18,19]$. As an emerging topic in IT management, green IT involves applying eco-friendly standards through the use of IT and is guided by several broad goals, such as sustaining the environment by using renewable resources, recycling and reusing manufactured IT products, and reducing waste and pollution by changing the patterns of production and consumption [20]. Nowadays, information technology offers software assets, hardware assets, tools, and practices that help organizations to increase environmental compliance in terms of management functions and business strategy. We are witnessing the emergence of a new concept (green IT), which Murugesan [21,22] defined as the study and practice of efficiently and effectively designing, manufacturing, using, and disposing of computers, servers, and associated subsystems, such as monitors, printers, storage devices, and networking and communications systems, with minimal or no impact on the environment. Green IT improves organizational performance by greening the information systems that organizations use for business processes. Molla [23] referred to green IT as the ability of organizations to deploy environmentally sustainable criteria for IT infrastructure life cycles.

Some of the most powerful business solutions for companies are enterprise resource planning (ERP) systems. Such systems have become a strategic tool for addressing complex tasks involving different departments, which usually have a common database. To increase the environmental friendliness of an ERP system, companies should be aware of the role of green IT practices in meeting ecological standards (i.e., energy efficiency, lowering greenhouse gas emissions, or using less harmful materials) when using information technology.

Green IT has the ability to generate competitive opportunities for developing sustainable ERP systems, which is a necessary step towards developing environmentally friendly organizations. Studies have been conducted on the topic of green IT [7,20]; however, these generally highlighted the principles and practices [21] and domain constructs of green IT [23]. Although the integration of IT with the environment is a requirement nowadays, the extent to which the adoption of green IT can be used to implement ERP systems remains unexplored. Many studies have addressed the organization of the adoption of green IT. For example, Murugesan [22] presented a holistic approach that provided specific ways to make IT infrastructure, applications, and practices environmentally sound. Additionally, Vom Brocke [6] provided green IT solutions to environmental problems involving information systems and IT hardware. However, there is a research gap regarding potential opportunities that IT solutions could provide for the development of sustainable ERP systems. Moreover, it is necessary to develop a comprehensive model that allows organizations to assess how green IT practices will be aligned with the skills, knowledge, and efforts that are required to move from the previous generation of ERP systems towards green ERP systems. A green IT framework was proposed by Philipson [24] as a way of understanding its components, such as equipment lifecycle, end-user computing, data center, and enterprise and enablement. Several studies have attempted to define the dimensions of ERP systems to evaluate their greenness [25]. Therefore, it is necessary for ERP project managers to discover how green IT solutions could be aligned with business processes to achieve green objectives.

Given the environmental impacts arising from IT, the purpose of this study is to explore the possibility of improving the environmental friendliness of ERP systems using green IT practices. The research questions which guided this study are (1) how can green IT practices be aligned with ERP systems; and (2) how does this alignment affect the sustainability of these systems?

This study answered the above questions by focusing on four Romanian economic sectors which are representative of market representation, flexibility, and contribution to gross domestic product (GDP).

The main contribution of this study is reflected in a double perspective. First, it provides a theoretical framework that can be used for the qualitative investigation of various aspects related to awareness about the use of green IT practices to develop green ERP systems. Second, considering the criteria of the proposed framework, companies can stimulate processes and activities to properly manage their ERP system in a greener approach. 
The paper is organized as follows. Section 2 describes the existing theory on the traditional ERP systems, sustainable ERP system, and green IT. Section 3 describes the theoretical framework used to evaluate the current status of companies from Romanian economic sectors related to the green ERP system criteria and green IT practices. Section 4 discusses the materials and methods used in the study. The analysis and discussion of the study results are presented in Section 5. Finally, Section 6 provides our conclusions and recommendations for further research arising from this study.

\section{Literature Review}

\subsection{Defining Green ERP Systems}

The contribution of informatics and communication technologies to extending globalization, as well as to increasing an organization's competitiveness and profitability, is unquestionable. Business managers are now trying to find solutions from the perspective of integrated management information systems (MIS) to satisfy the needs of decision-making at the operational level of the organization [26]. Thinking in terms of business processes, an integrated information system designed to effectively and efficiently support sharing data between and within functional areas leads to the requirement of an enterprise resource planning (ERP) system.

Based on unitary conception, ERP systems are core software programs used by companies to integrate and coordinate information from every area of the business [27]. ERP systems enable the management of all the company's processes by integrating its functions, such as human resources management, financial management accounting, decision support, sales, distribution, supply, production, and e-commerce. Another approach was suggested by Aloini et al. [28], which states that ERP systems assist enterprises in automating and integrating corporate cross-functions, such as inventory control, procurement, distribution, finance, and project management.

Two main principles underline ERP systems. First, the system integrates different software modules corresponding to various organizational functions, sharing a unified database to gather data from the system modules. Thus, the problem of the lack of integration between business functions and processes, as a major obstacle in simultaneously determining economic and managerial performance, is resolved. An ERP system includes an integrated workflows management tool that provides a complete overview of all active workflows and their statuses at all times [29]. According to Monk and Wagner [27], the use of ERP systems has evolved as a result of the complexity of hardware and software technology, as well as the emergence of a new vision about the reengineering of companies to shift from individual business functional areas to integrated business-process areas. Beyond this vision, today's ERP systems should consider the goals of sustainability [30], by embedding into them solutions and practices to contribute to reducing environmental problems. In this regard, the company's sustainability approach should involve replacing the current ERP system with a green solution to integrate the information, internal function, and processes with company environment performances [31]. Thus, to achieve the sustainability initiatives in business processes and in the core systems that support them, a green ERP system concept was proposed [31]. Despite the research in sustainable ERP (S-ERP) or green ERP system being in the introduction stage, some studies in this area have proposed opinions and guidelines for these concepts.

Starting from the idea that sustainability of information systems can be seen as a real solution to solving environmental issues, companies need a sustainable and integrated software solution to collect, integrate, and manage information, such as S-ERP or green ERP systems [7]. Some authors agree that the term "S-ERP" refers to a system that is able to support the sustainability initiatives, allowing practitioners to centralize data and activities among business functions within an organization into a single database, and provides reports that outline the sustainability performance [32,33]. The S-ERP system is the result of research in the field of the relationship between ERP and sustainability. Considering this a driver for sustainable business operations, Chofreh et al. [34] stated that an S-ERP system is driven by sustainability considerations that cover all aspects of the value chain. The S-ERP 
system can be approached as a holistic, integrative, and complete solution for sustainability business issues [34].

Another study emphasized a more general approach using the notion of green ERP systems that are environmentally friendly and allow organizations to cut costs while helping the planet [35]. Green ERP systems cover a wide range of issues in environmental sustainability [36]. While the current ERP systems are not designed to capture sustainability-related data, the philosophy of the green ERP system consists of a holistic and integrative approach of software applications to support the management of data and workflows in all sustainability dimensions [37]. Regardless of the terminology used (i.e., S-ERP or green ERP), a major issue is highlighted. Companies are forced to admit that sustainability performance is a key differentiating factor that requires improvements in IT infrastructure in line with green transformations that lead to the best business outcomes [38,39]. In this regard, the implementation of a green ERP system satisfies the organization's need to integrate resources and workflows embedded in their business functions with sustainability practices $[40,41]$.

\subsection{Defining Green IT}

Achieving a green ERP system in a company requires more than merely using IT in practices that involve measures of the development of greener applications and business transformation in adopting green initiatives [42]. Logically, organizations should align their IT with sustainable development [43]. The term "green IT" is now generally accepted as a system that embeds practices, initiatives, and measures with the final goal of reducing the negative impact of IT on the environment. Although there are many approaches in terms of its scope and coverage [44,45], green IT has become a necessity in IT management, being the first step toward the overall goal of sustainability. IT enables the creation of greener and sustainable development with a focus on the efforts of an organization in three directions [22]: (1) make IT systems and their use greener, (2) use IT in several ways to improve environmental sustainability in different areas of business activities, and (3) use IT in innovative ways to create awareness and promote sustainability among the employees and stakeholders. Studies have indicated that green IT aims to achieve economic viability and improved system performance and use, in accordance with an organization's social and ethical responsibilities. Thus, green IT incorporates the dimensions of environmental sustainability, the economics of energy efficiency, and the total cost of ownership, which includes the cost of disposal and recycling [21]. To address the environmental impact of IT, Murugesan's green IT definition focuses on a holistic approach to the tangible IT hardware, including the problems along four complementary paths: such are green use, green disposal, green design, and green manufacturing [21]. However, this definition lacks organizational perspective. According to Molla [46], the adoption of green technologies involves technological, organizational, and environmental contexts that are inherent when creating economic and environmental value. Another approach revealed that green IT provides a socio-technical perspective on the diverse complex phenomena of organizational sustainability [47].

Green IT has strategic relevance, which refers to the necessity of aligning business, sustainability, and IT domain. Porter's generic strategies can be supported by green technologies to create a competitive advantage in the business and sustainability domain. In this respect, green IT should be addressed as a strategic issue [48]. According to Harmon and Auseklis [49], green IT refers to the practice of maximizing the efficient use of computing resources to minimize environmental impact. Therefore, the solutions proposed by green IT can enhance the energy efficiency of data centers and computers, reduce the IT-related carbon dioxide emissions, and produce considerable cost savings. From this perspective, green IT might be considered an important tool that is able to reduce the environmental footprint of organizations [50]. As Murugesan [22] stated, green IT provides an opportunity for organizations to reconsider their IT systems in terms of environmental regulations and stakeholder's demands, while considering their social and ethical responsibilities.

Beyond green-IT-specific literature, there is evidence that a business's sustainability initiatives, such as green strategy, green enterprise resources planning, green supply chain management, and 
implementation of environmental technology, can build a positive brand image and influence the mindset of customers and investors [51]. As a result, the adoption of green IT can be considered a critical factor in the sustainability of businesses and the success of the low carbon economy.

As summarized in Table 1, many studies on green IT revealed a holistic approach to creating a more sustainable environment. Most of them addressed the following major issues: (1) green IT framework, (2) green IT principles and practices, (3) green IT strategies, and (4) green IT environmental impact.

Table 1. Major literature on green information technology (IT) and topics covered.

\begin{tabular}{|c|c|c|}
\hline & Green IT and Topics Addressed & \\
\hline \multirow{6}{*}{ Green IT framework } & Green IT Maturity Model & \multirow{6}{*}[43,46]{} \\
\hline & Equipment life cycle (Asset lifecycle) & \\
\hline & End user computing & \\
\hline & IT service management & \\
\hline & Enterprise and data center & \\
\hline & People practices & \\
\hline \multirow{3}{*}{ Green IT principles and practices } & Green IT adoption in management process & \multirow{3}{*}[20,21,34,35,51]{} \\
\hline & Sustainable enterprise resource planning & \\
\hline & Corporate social responsibility and green IT practices & \\
\hline \multirow{2}{*}{ Green IT strategies } & Enterprise green IT strategy & \multirow{2}{*}[21,36]{} \\
\hline & Strategic IT-business alignment & \\
\hline Green IT environmental impact & Green strategies for sustainable development & {$[22,39,44]$} \\
\hline
\end{tabular}

In line with the scope of this research, we refer to green IT as the many practices that help improve information systems and IT applications to optimize the management of data and organizational workflows through sustainability dimensions. Green IT promotes the relationship between ERP system and sustainability. Companies should innovatively exploit the power of IT to make their ERP system greener. In other words, a many eco-friendly practices are applied through the use of IT to create a more sustainable ERP system. Thus, we examined the greenness dimension of the ERP system that can be achieved by applying IT to create environmentally sustainable business processes and practices. According to the intrinsic specificity of Romanian economic sectors on one hand, and the existing theories in the literature on the other hand, this study provides a theoretical framework to define the appropriate criteria to evaluate the relationship between ERP systems and the use of green IT.

The next section provides a brief outline of the components of the theoretical framework that was measured to assess the manner in which IT is deployed to foster green ERP systems.

\section{Theoretical Framework of the Study}

This research was conducted using a general framework that can help with assessing the current status of companies from Romanian economic sectors related to the relationship between ERP systems and green IT. The theoretical framework has two components: (1) the green ERP system criteria including dimensions to evaluate sustainable indicators related both to IT infrastructure and implementation of an ERP system; and (2) the green IT practices focused on various aspects that can be used in a greener approach of an ERP system.

\subsection{Green ERP System Criteria}

Research on green ERP system development is still in the preliminary stage. Research is lacking in the identification of criteria for determining the greenness of ERP systems, despite various ERP guidelines that have been introduced by academics and practitioners. Since ERP systems are considered 
the foundation of green ERP systems, the success of their implementation is determined by the attainment of sustainability objectives in terms of business functions, internal organizational processes, or corporate strategies. As green ERP systems are concerned with addressing the environmental initiatives that cover all aspects of the business functions and processes, the theoretical framework of this research provides dimensions to evaluate the greenness of ERP systems, which could be split into two fields. The first field includes criteria to evaluate ERP system through a sustainable development process. This involves the concept of sustainable software that Naumann et al. [52] defined as software whose development, deployment, and usage results in minimal direct and indirect negative impacts or even positive impacts on the economy, society, human beings, and the environment. Previous studies [52-54] highlighted a number of criteria that have been proposed to evaluate software sustainability, including attributes that can be defined as a measure of system extensibility, interoperability, maintainability, portability, reusability, scalability, and usability. In this paper, to assess the ERP software quality from the sustainability perspective, we selected appropriate criteria, including:

1. Energy Efficiency: This criterion considers the optimization of the energy consumption of the ERP system in relation to resource use in the data center.

2. Feasibility: This quality criterion evaluates the effects of the ERP system development and implementation on sustainable development. In a broad context, aspects related to business travel, asset life cycle, or user behaviors are considered.

3. Portability: Refers to the efforts to port ERP software from one hardware platform or software environment to another.

4. Usability: This criterion covers the understandability, learnability, and operability of ERP software, addressing the extent to which the system can be used by specific users, to achieve effectiveness, efficiency, and satisfaction in a particular context of use.

These criteria intersect IT in the area of green IT practices that can be used to determine how the ERP software can be sustainably developed. The main goal of considering green IT initiatives in ERP software sustainability is to improve the sustainability of their interrelations.

The second field includes criteria for assessing the sustainable management process related to ERP implementation. From the management perspective, Chofreh et al. [25] proposed a guideline to effectively implement a sustainable ERP system within the organization including decision-making levels, sustainability paradigm, strategic management, and project management. Concerning the ERP implementation process, Kogetsidis et al. [55] suggested the benefits of properly selected ERP systems in terms of time and cost reduction in processes, faster transaction processing, operational performance improvement, financial management, customer services, web-based interfaces, and more effective communication. An extended vision related to ERP system implementation was highlighted by Lubin and Esty [56], who proposed a roadmap to implement sustainability initiatives in organizations, encompassing five main areas: leadership, techniques and models for value assessment, strategic alignment, integration, and reporting and communication. Sahran et al. [57] proposed guidelines for implementing ERP systems in small- and medium-sized enterprises that included, among others, management processes, recruitment of project team members, ERP vendor and software selection, and business process re-engineering.

In this study, the sustainable management process of ERP system implementation emphasizes its alignment with green IT practices to reduce IT's environmental impacts. Summarizing the studies on ERP systems and considering how green IT makes the systems "greener", the criteria that we propose as a part of the integration of sustainability elements into the ERP system are as follows:

1. Top management support [58,59]: This criterion addresses the role and importance of senior management in incorporating ERP system goals into a holistic and integrative vision that addresses sustainability issues, which covers all aspects of business processes. 
2. Strategic alignment [59-61]: The aim of this criterion is to investigate the linkage of environmental IT initiatives with sustainability strategy in order to express how the application of green IT practices is supposed to fulfill the requirements of the ERP system.

3. Vendor support and reputation $[62,63]$ : This criterion refers to ERP system vendor profiles from the perspective of their environmental values related to energy efficiency of software development, good reputation in using IT-based environmental initiatives, or business processes certified for environment friendliness.

4. User practices and attitude $[64,65]$ : User awareness of environmental issues is one on the most important criteria for assessing the sustainable management process of ERP implementation. It refers both to practices and attitudes when dealing with green IT initiatives that lead to behavioral change in using the ERP system (e.g., reducing paper use and printing, applying teleworking and collaboration, using screensavers, turning off the system when not in use, and programing computers to automatically power down).

Synthesizing the aspects discussed above, the set of criteria used to evaluate the ERP system by incorporating green IT is presented in Figure 1.

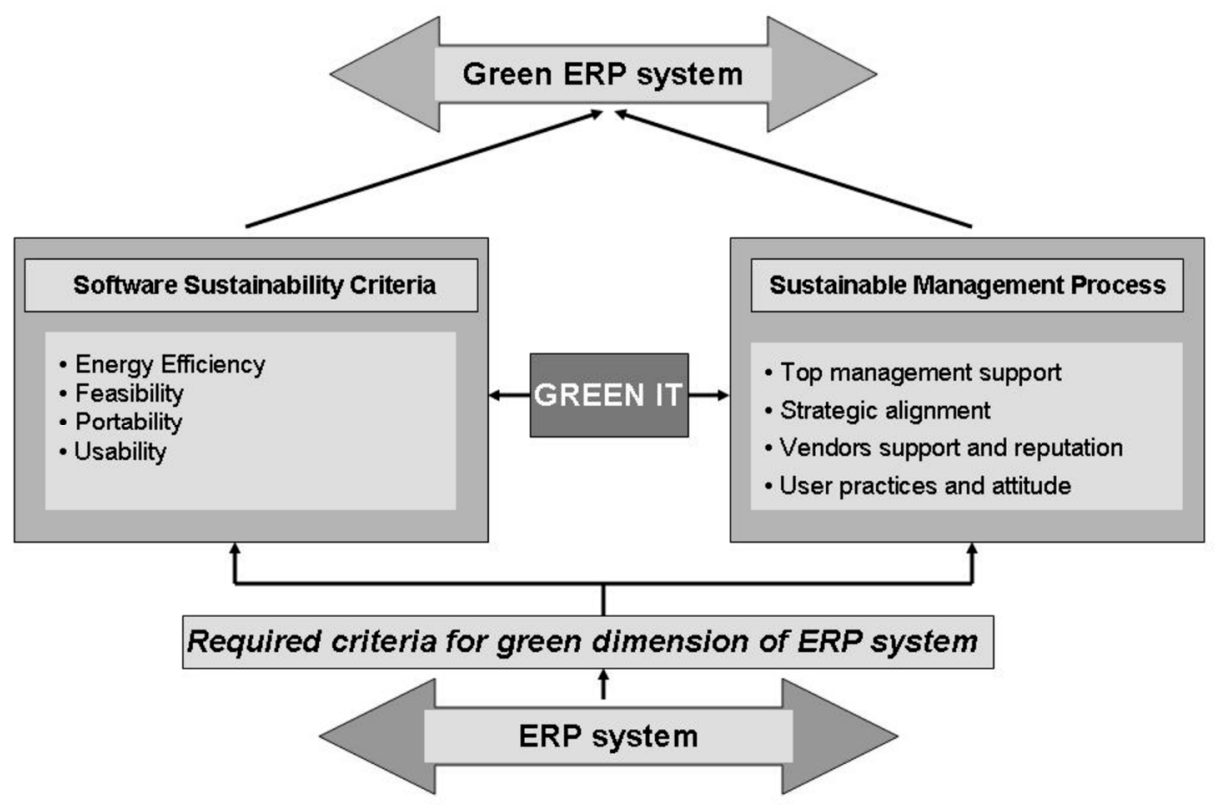

Figure 1. Green enterprise resource planning (ERP) system criteria.

\subsection{Green IT Practices}

To effectively assess the contribution of green IT to more environmentally friendly ERP systems, a theoretical framework that includes the main practices used to reduce IT's environmental impacts is required. Many studies focused on the green IT framework for developing a better adoption process at the organizational level. Molla [46] identified three drivers of green IT: economical, regulatory, and ethical drivers. Bose and Luo [66] proposed an integrative framework for undertaking green IT initiatives based on technological, organizational, and environmental contexts. To assess and implement green IT practices, Desai and Bhatia [67], also Foogooa et al. [68] introduced a green IT maturity model (GITM) that can be used to measure an organization's maturity in being green. Their model focuses on five pillars: data center and facilities, end user computing, asset lifecycle, IT service management, and people practices. A research model for organizational green IT adoption was proposed by Deng and Ji [69] to show the relationship between the determinants of this process and organizational competitive advantage. The problem of addressing ERP systems in a greener manner is linked to interrelated perspectives provided by the core green IT constructs, such as attitude, policy, practice, technology, and governance [70]. 
Based on our literature review, we propose green IT practices and technologies that can lead to integrating environmental perception into green ERP system evaluations. Thus, according to the green IT maturity model suggested by Desai and Bhatia [67], the following three focus areas are included in the theoretical framework in our research: data center and energy efficiency, asset lifecycle, and people practices.

\subsubsection{Data Center and Energy Efficiency}

Enterprises consider the data center as the main place of their operations, including two of the most important types of ICT equipment: servers and storage devices. Usually, servers are the biggest consumers of energy, continually increasing operational costs. In this context, the use of ERP systems implies software and hardware resources consumption, which becomes a critical environmental impact issue. Therefore, to improve data center efficiency, companies should consider green IT solutions in terms of energy efficiency, such as:

1. Storage consolidation: The concept of centralizing and sharing storage resources among numerous application servers. Storage consolidation allows organizations to increase the use of IT resources so that energy consumption for data storage can be minimized. Depending on the systems and circumstances involved, storage consolidation can be achieved in many different ways, such as running multiple application schemas in one single database, hosting multiple databases on a single platform, reducing data volume, and eliminating redundant data through de-duplication and compression.

2. Server virtualization. Widely adopted as a green IT initiative, virtualization enables data centers to consolidate their physical server infrastructure by hosting multiple virtual servers on a smaller number of more powerful servers, reducing the data center's energy demands [21]. According to Barroso and Hölze [71], virtual servers use less power and have higher levels of efficiency than standalone servers. Although virtualization technology allows the reduction of power consumption by reducing the overall number of devices, in practice, most data centers' power consumption continues to rise because the devices are becoming increasingly powerful and use more electricity. However, from a green IT perspective, this technology helps organizations to achieve some of the objectives of their environmental policy.

3. Automated power management software: Refers to systems management and automation software that is able to force system shutdowns during hours of inactivity (e.g., evenings and weekends). Software-based solutions can enforce organizational policies regarding the use of power saving features (turn off monitor, turn off hard drive, put system in sleep mode) so that power consumption is minimized during operational hours [72].

4. Thin Clients: There are workstations with minimal hardware configurations, which are typically designed with only rudimentary processing and memory functionality. Several applications are hosted on a central server and then transmitted to the thin client via a network communication process or virtualization technology. Using of thin clients could significantly save power because their goal is essentially to act as a simple terminal, without memory resources, central processing unit (CPU), or a full operating system [72]. A report conducted by Info-Tech Research [73] highlighted that a typical computer uses up to a 250-watt power supply, a thin client uses a 4.8-watt power supply, so the reduction in electricity usage is $97.98 \%$.

\subsubsection{Asset Life Cycle}

This focus area of green IT framework is an important aspect in terms of the overall impact on the sustainability of an ERP system. The asset life cycle covers the procurement of data center equipment and recycling at the end of its life cycle in an environmentally responsible fashion [74].

1. Procurement: Procurement is a major issue faced by green practices related to the use of ICT, involving two crucial points: the nature of the equipment itself, and the nature of the suppliers of 
the equipment. According to Uddin and Rahman [74], the first may comply with environmental standards, such as Energy Star and the Electronic Product Environmental Assessment Tool (EPEAT), which provide a methodology and guidance for purchasing. The second point is linked to the suppliers' own green strategies and carbon footprints. These strategies include important purchasing criteria, such as the supplier's environmental values in the design and manufacture of equipment, its compliance with relevant environmental laws and codes of practice, and whether the supplier reclaims and recycles old equipment from customers [74].

2. Recycle and reuse: To reduce the organization's environmental impact, recycling IT equipment is an appropriate solution to extend their life cycle. Although the periodic replacement of IT equipment is natural, many organizations do this too early, increasing the waste sent to landfills. To harness the green dimension of an ERP system, some initiatives focused on equipment recycling and reuse should be promoted. Thus, recycling can help with recovering valuable materials and may reduce the greenhouse gas emissions associated with production of new equipment. Reuse avoids the need to extract more valuable resources or expend energy in the manufacture of new equipment [75].

\subsubsection{People Practices}

Due to the greatest effect on the green attitudes and behavior of the organization's workforce, people practices is the most important area of the green IT framework. Studies indicated that user awareness can offer twice the energy savings compared to centralized power management solutions [67]. Concerning the impact on green ERP systems, the following people practices are considered:

1. User education: This is the basic step for individuals and organizations that could be adopted to directly help with the greening of the ERP system. Many practices do not involve the purchase of any new technology, but simply refer to techniques and behavior that people should adopt, such as using screensavers, using e-mail, turning off personal computers (PCs) when not in use, recycling printer paper, and printing less [76].

2. Printer consolidation: Printers are commonly used devices in any business that consume a large amount of energy and paper. Printers themselves are environmentally unfriendly devices because they are built from materials that are difficult to recycle or are toxic. Therefore, as an important green IT solution, printer consolidation addresses the processes that optimize the organization's printer fleet to decrease the cost of hardware, consumables (paper, toner, ink), electricity, and maintenance.

3. Telecommuting: Given the awareness of global warming caused by greenhouse gases emissions, many companies wish to reduce travel to cut costs and decrease the negative impact of travel on the environment. Telecommunication-related technologies (e.g., teleconferencing and video-conferencing) are common solutions to reduce the need for business travel that could help to green the use of an ERP system. Telecommuting technologies allow working at a distance, and can be used for some remote management processes, document management, and sharing knowledge.

Based on the three focus areas presented above, we propose a green IT framework that could help with understanding how organizations should better identify the green practices that need to be applied in their ERP system to minimize the environmental impact of IT (Figure 2). 


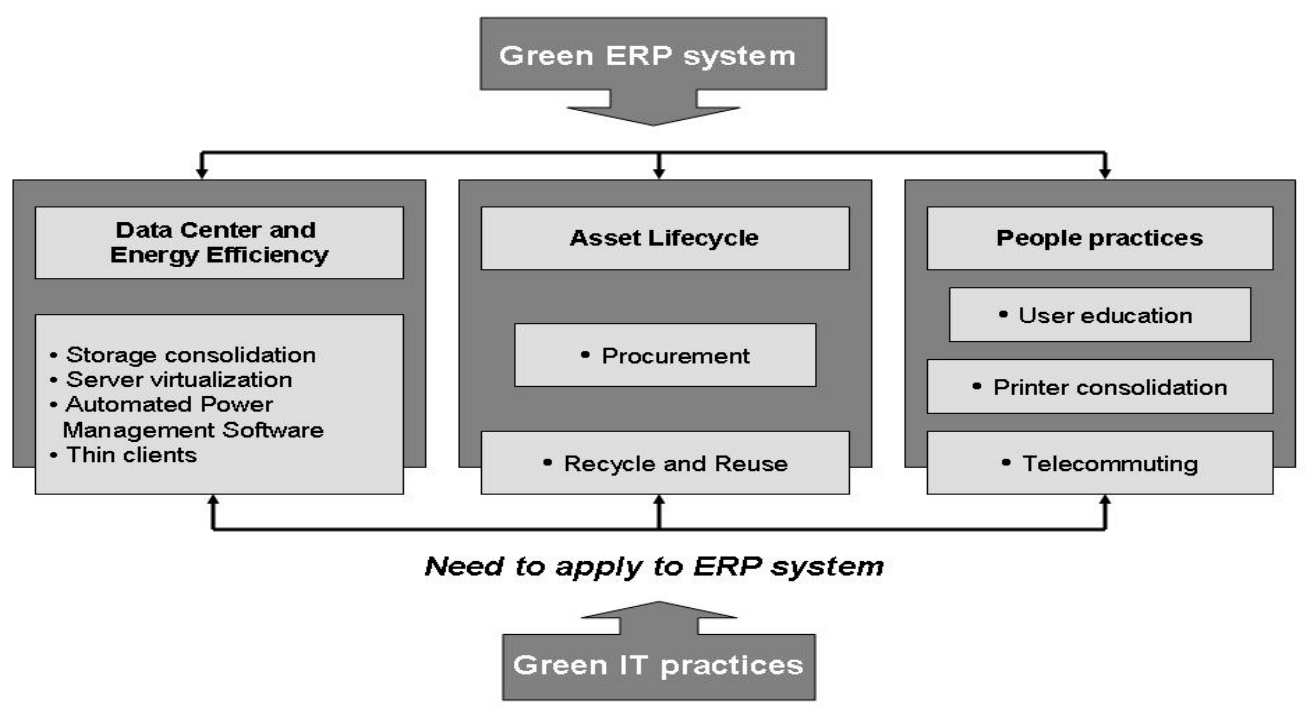

Figure 2. Green IT framework for constructing a green ERP system.

\section{Material and Methods}

\subsection{Data Collection and Sampling}

In Romania, reducing the environmental impacts of IT is an important topic, especially for large companies. Small- and medium-sized enterprises (SMEs) still generally do not address the environmental impacts of IT, due both to financial reasons and the unwillingness of leadership to address such impacts. Therefore, in this study, we selected 17 companies across four Romanian economic sectors and gathered data about their views and practices that influence the development of a green ERP system. We focused on the industry sectors in Romania that have operated successfully for many years. The National Strategy for Competitiveness 2015-2020 [77], which has been adopted by the Romanian Government, identified 10 economic sectors with a competitive advantage; these correlate with intelligent specialization areas mentioned in the National Strategy of Research, Development, and Innovation 2014-2020 [78]. The economic sectors with competitive potential include the automobile and automobile components industry, information and communication technology, health, and pharmaceuticals. In this study, we also focused on the utilities sector, including companies related to energy transport and distribution, and heat energy distribution. A study conducted in 2017 about managers' perceptions of the impact of digitalization on Romanian companies [79] revealed that managers believed that the utility industry was traditionally slow in terms of digital transformation compared to the telecommunication or manufacturing sectors. Based on this empirical evidence, we considered it relevant for this study to perform a survey of Romanian companies from the economic sectors listed below (Table 2) to determine whether green IT practices are able to increase the sustainability of ERP systems. The survey was conducted between March 2018 and March 2019.

Table 2. Number of companies by economic sector.

\begin{tabular}{ccc}
\hline Economic Sector & Number of Companies & Time Line to Conduct Survey \\
\hline Manufacturing & 7 & March-May 2018 \\
Telecommunication & 2 & June-July 2018 \\
Pharmaceuticals & 3 & October-November 2018 \\
Utilities & 5 & February-March 2019 \\
Total & 17 & \\
\hline
\end{tabular}

On the basis of the criteria presented in Section 3, a simple questionnaire for collecting observation data was used. To capture information about organizational green IT practices that could be used 
to foster the greenness of the ERP system, the questionnaire was distributed to 180 respondents and included questions structured within the following categories: Category 1: General information concerning the respondent and their organization; Category 2: Awareness about software sustainability; Category 3: Awareness about sustainable management process; and Category 4: Awareness about green IT initiatives and practices. The respondents were selected through the non-probability method by using convenience sampling. This type of sampling allowed us to conduct the preliminary stage of the survey under the time and cost limitations of the research. Moreover, by using convenience sampling, we had an ease of access to the respondents, who were arbitrarily selected among the Chief Information Officers (CIOs), IT managers, Chief Technology Officers (CTOs), ERP project managers, and other business managers from each of the 17 companies.

\subsection{Research Model and Methods}

Based on the conceptual research model shown in Figure 3, we conducted a study to investigate the extent to which different green IT measures can increase the sustainability of ERP systems.

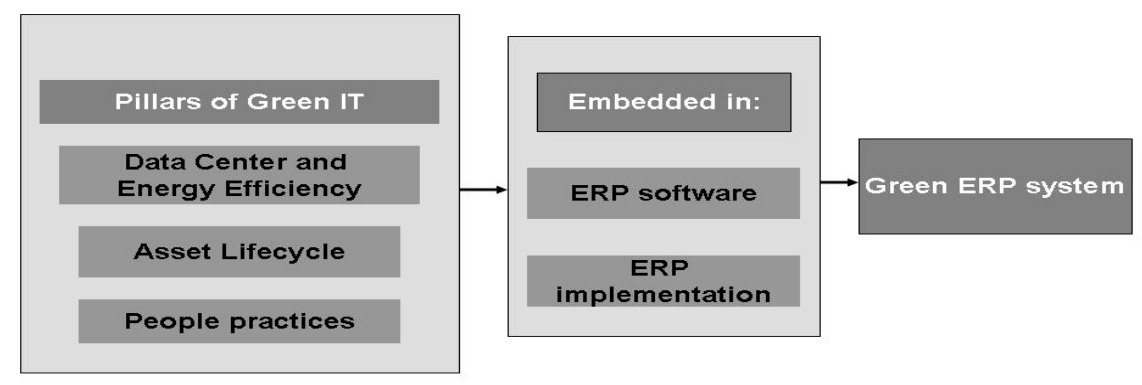

Figure 3. Conceptual research model.

This research builds on an inductive approach [80] which involves exploring the behaviors of companies in order to generate a hypothesis. Using inductive reasoning, we made specific observations related to the relationship between green IT initiatives and ERP systems. Based on this, we developed the following hypothesis:

Hypothesis1 (H1): Green IT projects are positively related to the sustainable development of ERP systems.

As the information and data for the components of the above conceptual model are unstructured, green ERP system criteria and green IT practices were assessed using the observational research method.

This is an obvious method for carrying out research in social science that involves the direct observation of phenomena in their natural setting. Therefore, the observational research allowed us to understand the behavior of companies related to their awareness about using green IT practices to develop green ERP systems. Given the aims of the study, the research methodology involved the use of mixed methods research within the same paradigm. Thus, our approach was based on observational research as the qualitative method that seeks to describe a set of variables related to the criteria presented in Section 3. Due the fact that we were interested in quantifying the behaviors that we observed concerning the attitude toward green IT practices that improve the green dimension of ERP systems, structured observation was used. This is a common type of observational research where the emphasis is on gathering quantitative data rather than the qualitative data. Basically, to record the level of awareness about green ERP system criteria and green IT practices, different categories of items were defined (i.e., awareness about software sustainability, awareness about sustainable management process, and awareness about green IT initiatives and practices). To collect the data, a questionnaire was sent to respondents that were selected by convenience. The full questionnaire is provided in Appendix A.

This questionnaire was distributed to 180 respondents, but only 146 from 17 companies were considered complete for data analysis. Most questions in the online survey were structured using a 
seven-point Likert scale: (1) strongly disagree (SD), (2) disagree (D), (3) fairly disagree (FD), (4) neutral $(\mathrm{N}),(5)$ fairly agree (FA), (6) agree (A), and (7) strongly agree (SA). The gathered data represent the level of awareness of the companies related to the criteria of green ERP systems and green IT practices. In this regard, the items in categories 2-4 from the questionnaire were used to establish the level of agreement of the economic sectors, related to negative, neutral, and positive attitudes. To determine the score for the levels of agreement for each economic sector, for each category of items, the statistical data were processed using the following expressions:

$$
\begin{gathered}
\mathrm{LA}_{m}=\frac{n}{i} \times \mathrm{W}_{s j}, i=1 \text { to } n ; m=1 \text { to } 4, \\
\mathrm{~W}_{s j}=\left(\sum_{k=1}^{t s} X_{k j}\right) / 100, k=1 \text { to } t_{s,}
\end{gathered}
$$

where $\mathrm{LA}_{\mathrm{m}}$ is the level of agreement score of the economic sector, $m$ is the number of the economic sectors, $n$ is the total number of companies, $i$ is the number of companies in the economic sector, $\mathrm{W}_{\mathrm{sj}}$ is the level of agreement of the category on type of attitude $j$ (i.e., $j=1$ negative attitude; $j=2$ neutral attitude; $j=3$ positive attitude), $s$ is the category number of the questions $(s=2-4), t_{s}$ is the total number of items from the category $s, k$ is the item's number, and $X_{k j}$ is the level of agreement for item $k$, corresponding to type of attitude $j$.

Questions in category 4 regarding the awareness of green IT practices allow the respondents to rate their opinion with yes or no. Observing the data collected from the online survey, the following results are highlighted.

\section{Results and Discussion}

\subsection{General Information}

Concerning the level of education, the data revealed that all 146 respondents had a bachelor's degree $(100 \%), 64$ respondents had taken a postgraduate course $(43.8 \%), 71$ had Master's degrees (48.6\%), and eight had a PhD degree (5.4\%) (Figure 4).

The survey results show that the respondents from the companies selected are represented by IT managers (48\%), ERP project managers (27\%), other business managers (21\%), $2 \%$ Chief Information Officer CIOs, and 2\% Chief Technology Officer CTOs (Figure 5).

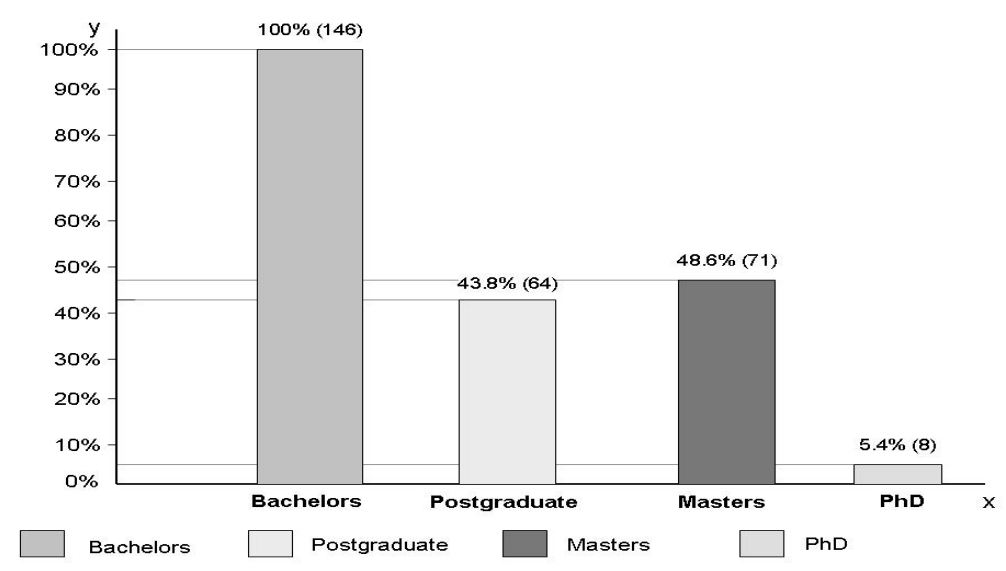

Figure 4. Level of education among the respondents. 


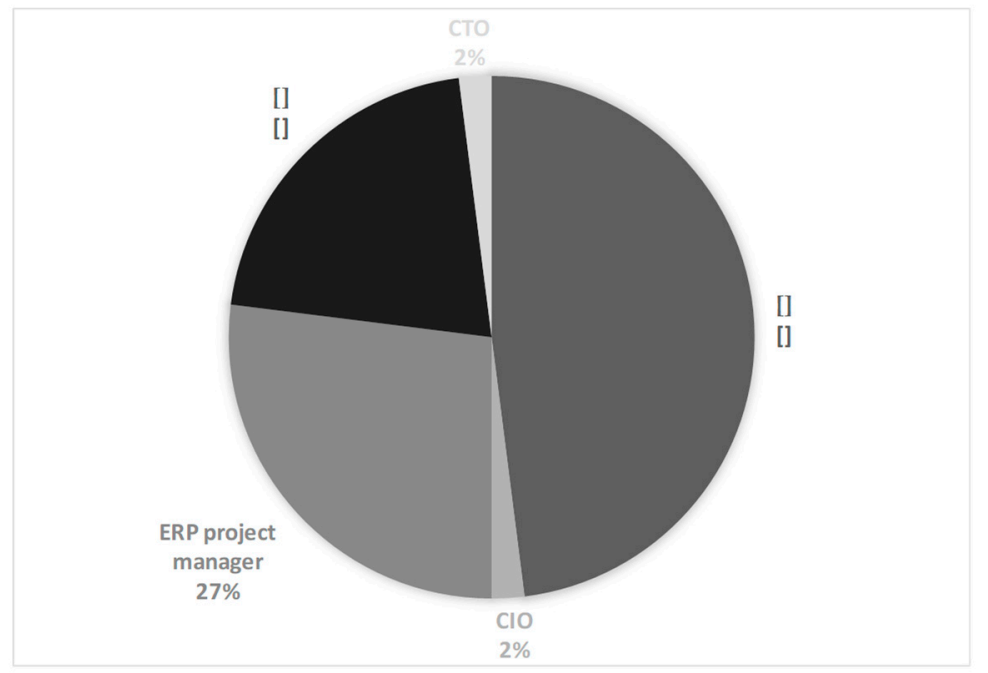

Figure 5. Position in organization.

\subsection{Awareness of Software Sustainability}

Questions in this category were related to the software sustainability aspects of an ERP system in order to align with environmental requirements. By investigating the respondents' attitudes through the Likert scale, we identified the level of agreement concerning the criteria that deal with sustainable ERP software. The overall level of agreement related to category 2 from the questionnaire on type of attitude (negative-SD/D/FD, neutral $-\mathrm{N}$, and positive-FA/A/SA), for each economic sector are shown in Appendix B.

The survey suggests that significant differences exist in terms of software sustainability awareness related to economic sectors. According to the collected data, the companies from the utilities sector indicate a negative attitude toward actions that can improve the sustainability of ERP software $(13.66 \%)$, followed by the pharmaceuticals sector $(11.05 \%)$, telecommunication sector $(8.58 \%)$, and manufacturing sector $(6.84 \%)$. This situation is attributed to the current understanding of software sustainability, which is a vague term especially for companies in the utilities sector that are poorly reformed.

Companies in the telecommunication sector have the highest level of agreement concerning positive attitudes toward applying various actions to improve the sustainability of ERP software $(37.23 \%)$. They are focused on optimization of resource usage during ERP software tasks, considering the provision of energy efficiency conditions related to attributes that reflect the software quality (i.e., portability, feasibility, usability). In the manufacturing sector, we noted a positive level of agreement of only $6.14 \%$, which suggests less interest in developing ERP software with minimized environmental impacts. The results of the survey related to this category show that awareness about software sustainability is heterogeneous through the selected economic sectors (Figure 6). We found a substantial level of neutral attitude in the telecommunication and pharmaceuticals sectors, revealing a misunderstanding about sustainable software aspects as a condition of developing green ERP systems. 


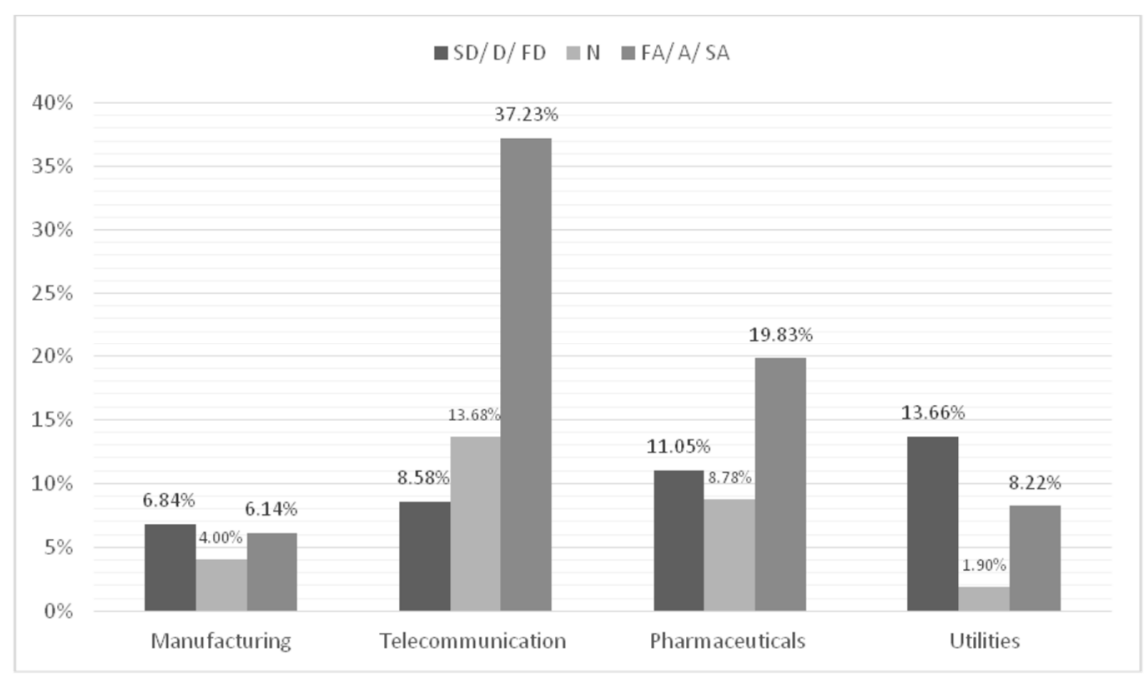

Figure 6. Awareness of software sustainability on the economic sectors.

\subsection{Awareness of Sustainable Management Process}

This section is related to the third category of the questionnaire, which included questions about how the organization deploys a sustainable management process to implement the ERP system. The survey investigated the respondents' attitudes using a Likert scale covering the criteria such as top management support, strategic alignment, vendor support and reputation, and user practices and attitudes. Appendix $C$ presents the overall level of agreement concerning this category, structured by economic sector. According to the descriptive data, the telecommunication sector had the highest overall level of positive agreement regarding the sustainable management process in implementing the ERP system (28.9\%). We observed that companies from this economic sector consider at least two criteria to be important when addressing sustainability issues when implementing the ERP system: top management support $(84 \%)$ and user practices $(87 \%)$. Between the four economic sectors, major differences were observed in terms of awareness about the sustainable management process. The manufacturing sector, with a score of $6.75 \%$, and utilities sector, with a score of $6.29 \%$, both have a poor level of positive attitude concerning the criteria that are embedded in the sustainable management process that leads to the implementation of a green ERP system. This may be because companies from these sectors are still suffering implementation failure because of non-performing or underperforming leadership, the lack of strategic alignment between the IT and their business goals, and missing user behavior in terms of eco-responsible practices. Even the pharmaceuticals sector had a higher level of negative attitude $(9.86 \%)$ than the manufacturing $(4.56 \%)$ and utilities $(4.03)$ sectors, the positive level of agreement of $17.45 \%$ suggests a significant awareness concerning the criteria that are required for the green dimension of an ERP system (e.g., top management support, vendor reputation, user behaviors). The sustainable management process in implementing ERP systems can be considered an enabler determining the greenness of this system. Despite this, the overall positive attitude about the criteria that we propose to be integrated into ERP system implementation from a sustainable perspective is reserved on the economic sector level. We observed a certain level of negative attitude toward sustainable management processes that minimize the benefits of evolution to a green ERP system (Figure 7). 


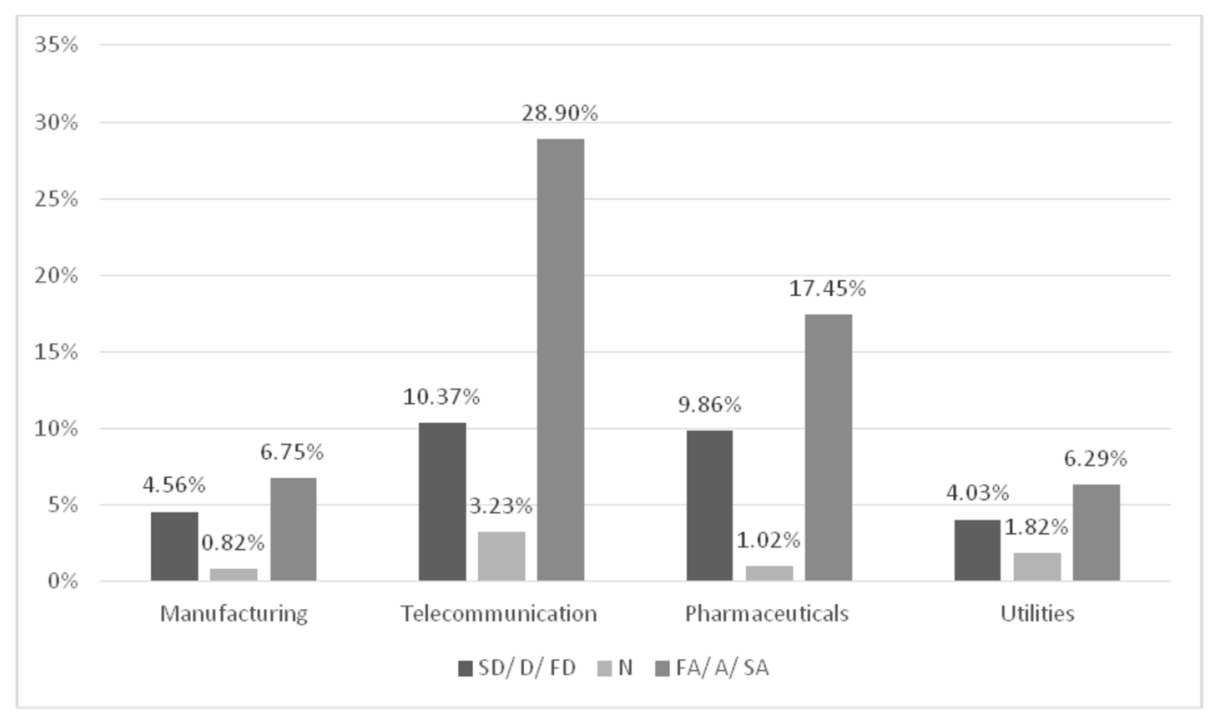

Figure 7. Awareness about the sustainable management process on economic sectors.

\subsection{Awareness of Green IT Initiatives and Practices}

This is the fourth category that aimed to explore the level of awareness of green IT initiatives and practices that organizations apply to their ERP system to minimize the environmental impact of IT. Companies selected in the study provided information on various topics related to how green IT initiatives are able to improve the ERP system in a sustainable manner. To present the results of the survey, two approaches are used. First, Appendix D presents the respondents' attitudes distributed on a Likert scale related to the first five items from the questionnaire about how green IT solutions offer environmental benefits when using an ERP system. The summarized data on each economic sector are shown in Figure 8.

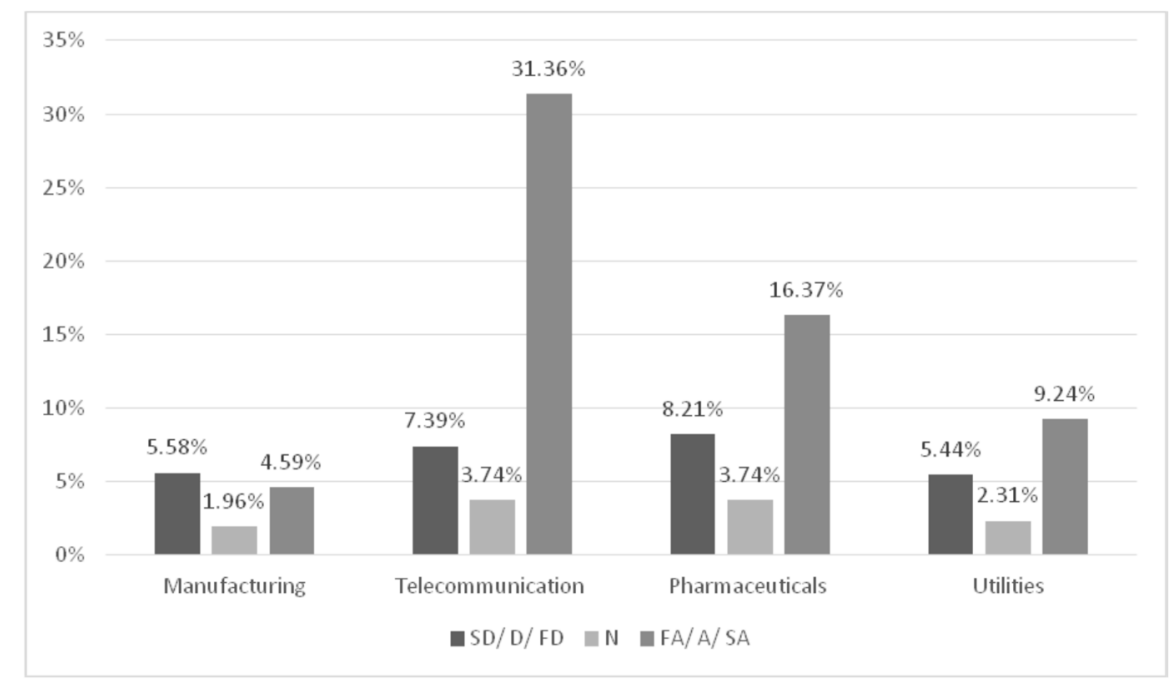

Figure 8. Awareness about green IT initiatives and practices.

The results show that the telecommunication sector (31.36\%) had the highest value of positive agreement, unlike manufacturing, which only had $4.59 \%$. This finding is likely due either to the presence of more qualified employees in the telecommunication sector, who are aware of the relationship between environmentally friendly IT practices and the use of an ERP system, or by better leadership who develop a holistic IT strategy based on a sustainable vision. In analyzing the data, we also recorded 
a positive attitude related to how green IT solutions offer environmental benefits when using an ERP system for the pharmaceuticals (16.37) and utilities (9.24) sectors.

From the perspective of negative attitude related to awareness of green IT practices, the levels of disagreement are similar, displayed by some common aspects for all the companies. There are no official regulations enforcing green IT practices; therefore, this topic is not included in organization policies. There is no appropriate training for employees that help to motivate them to start environment-related initiatives for using IT software and hardware infrastructure.

Our second approach involved representing statistical results graphically, revealing the awareness of specific green IT practices the organization applied to operate their ERP system (e.g., storage consolidation, virtualization, automated power management, IT procurement, IT recycling and reuse, ERP system vendor compliance, etc.). These practices were analyzed within the companies as follows:

\subsubsection{Green IT Solutions to Reduce Energy Consumption Related to ERP Systems}

These include the most popular approaches to achieving energy efficiency, such as storage consolidation, server virtualization, automated power management (APM), and thin clients. According to the summarized data collected from the respondents from each economic sector, the statuses of the applications of green IT solutions in the selected companies are presented in Figure 9.

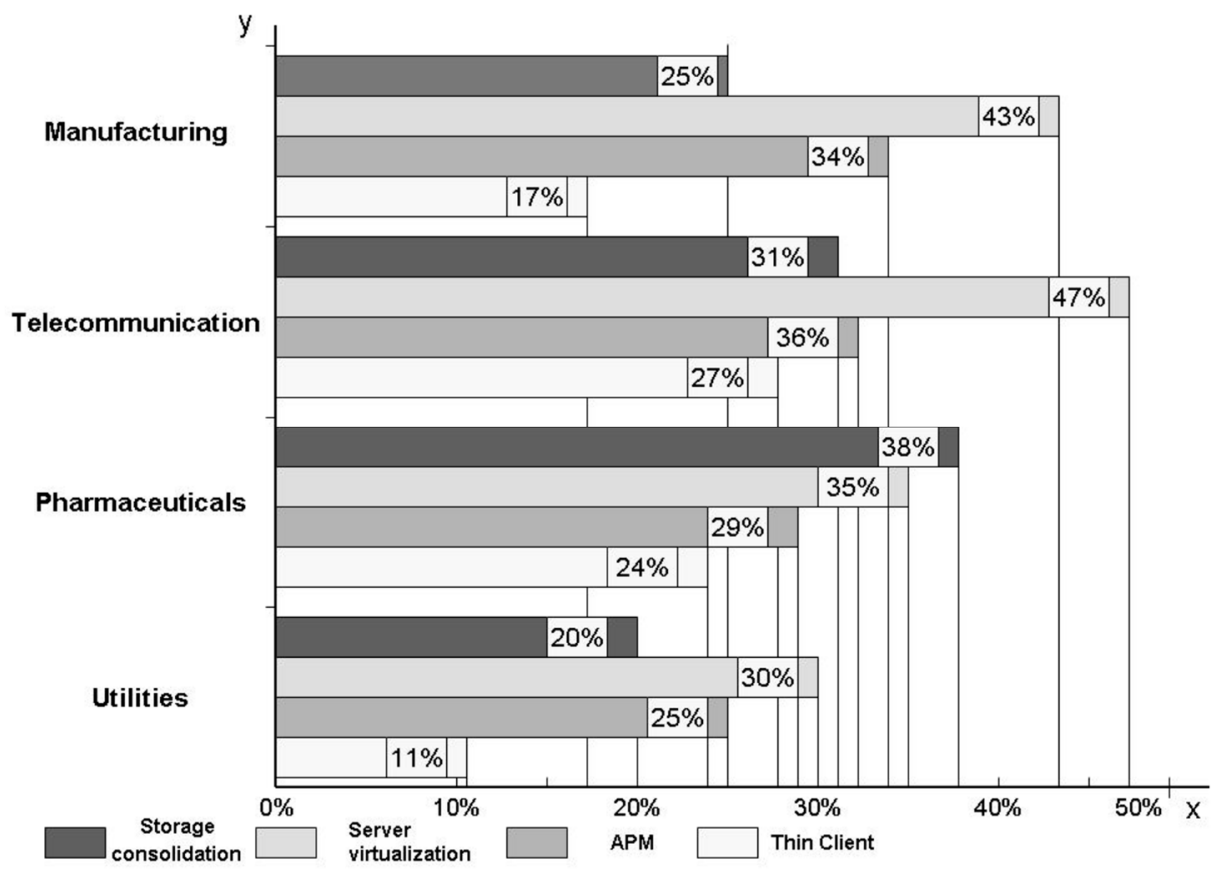

Figure 9. The status of applications of green IT solutions.

The data show that pharmaceuticals companies more frequently apply storage consolidation as a solution to reduce energy consumption than the others, whereas telecommunication and manufacturing companies use virtualization as the main practice to decrease the number of devices running in the server room. Large organizations in these sectors are in a better position to take advantage of storage consolidation and server virtualization since they have the budget to deploy solutions to improve energy efficiency and power performance.

Concerning the implementation of thin clients, although they can help reduce energy consumption because they produce less heat than traditional PCs, the overall percentage of this solution is smaller than other green IT initiatives. A possible motivation for this finding is that even though the thin client measure is easily adoptable, it would not become a common practice because their action as a simple terminal eliminates the active participation of the users. To enforce this solution, companies must educate their employees to change their computer behavior to save energy and decrease the cost of 
maintenance of the information systems. Telecommunication and pharmaceutical enterprises apply this green IT solution more than the others because of the awareness of ICT departments in finding appropriate solutions for power saving in all aspects of business.

The automated power management solution is preferred by companies from telecommunication and manufacturing sectors, followed by pharmaceuticals and utilities companies. This is a basic energy conservation solution that a large proportion of organizations have only partially implemented. All the companies involved in the study have many desktops that lead to considerable expenses that would be reduced by applying power saving features for systems. As automated power management basically refers to some systems management software that are able to force system shutdowns during hours of inactivity, the adoption of this measure is a problem of top management support and user education. Therefore, to enhance their IT infrastructure to foster the green dimension of the ERP system, companies should apply any one or a combination of the above green IT solutions.

\subsubsection{ERP System Vendor Complies with Software Sustainability Criteria during Application Design}

This is related to the question about how ERP system vendors conform to the software sustainability criteria in the design of ERP applications. According to the number of respondents from each economic sector (38 from manufacturing, 36 from telecommunication, 41 from pharmaceuticals, and 31 from utilities), the percentages of the answers are presented in Figure 10a-d.

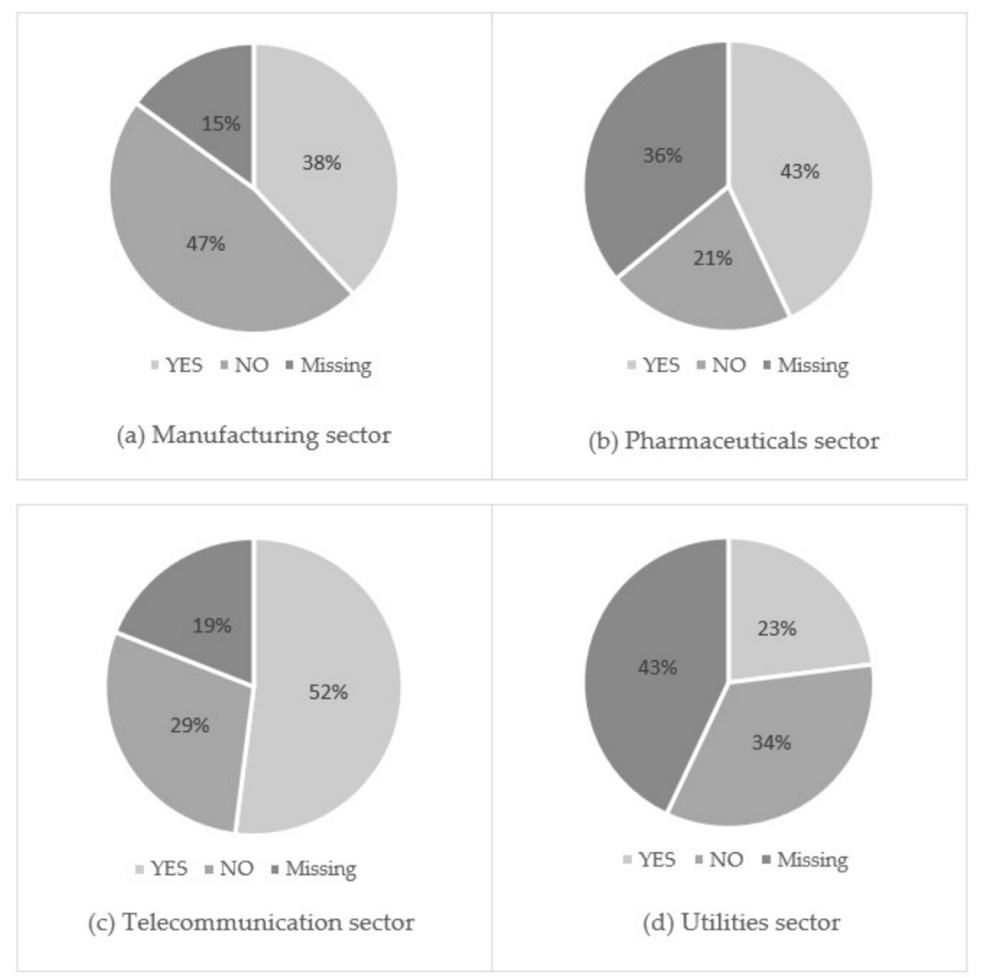

Figure 10. (a-d) ERP system vendor compliance to software sustainability criteria.

In the manufacturing and utilities sectors, there is a lower level of awareness about the need for ERP system vendor compliance with software sustainability criteria. The percentage of negative answers are significant compared to the other two sectors. These results suggest little interest in ERP suppliers that have a good reputation for using sustainable criteria to develop software applications. The higher level of awareness of the green ERP system for this dimension was noted in the telecommunication sector $(52 \%)$, followed by the pharmaceuticals sector $(43 \%)$. This shows a greater willingness of companies to use business processes certified for environment friendliness, not only implementing some simple energy efficient solutions to reduce operational costs. 


\subsubsection{IT Procurement Policy}

With this item in category 4 , we wanted to investigate the IT procurement policies of companies in terms of making an overall impact on the sustainability of the ERP system. The respondents were asked about the organization's initiatives that help make more informed choices when purchasing new equipment, including aspects such as the supplier's environmental values in the design of equipment and its compliance with environmental regulations and best practices. Figure 11 presents the results across the four economic sectors, structured by type of opinion.

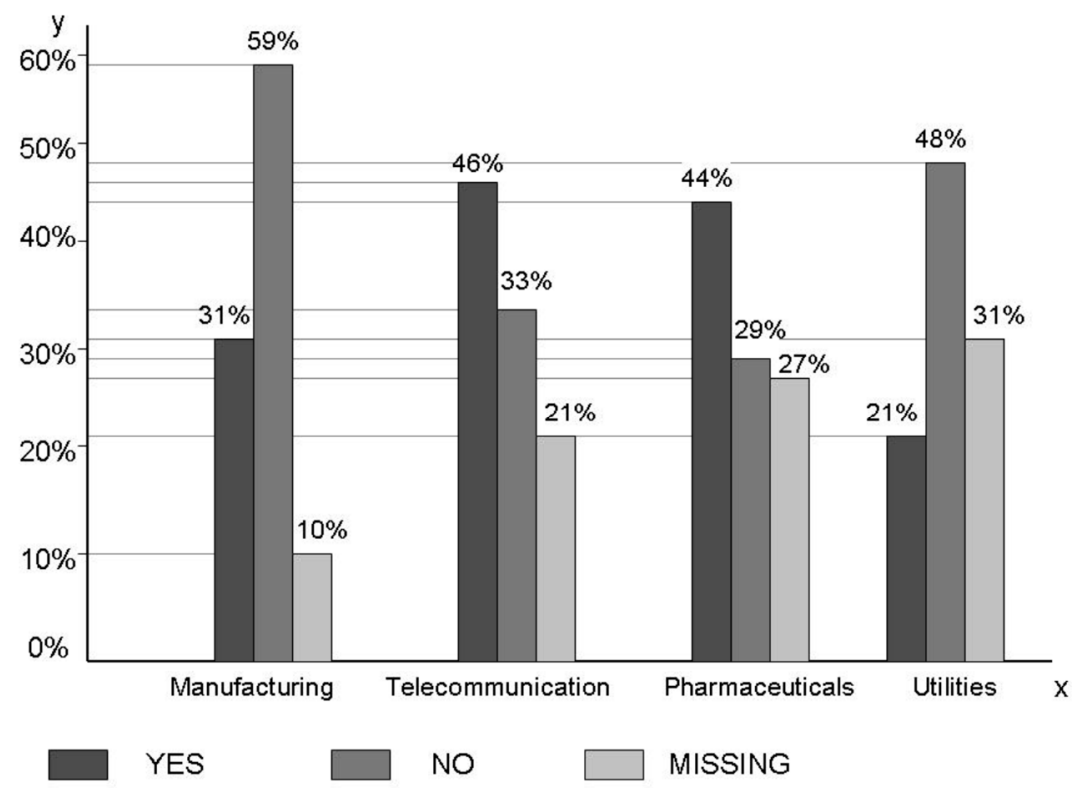

Figure 11. Awareness of IT procurement policy.

The results show that the higher percentage of positive answers was provided by the telecommunication sector $(46 \%)$, and pharmaceuticals sector $(44 \%)$. Over one-quarter of the opinions of respondents from these companies were negative, suggesting an important misunderstanding related to the need for an IT procurement policy in aligning the ERP system with sustainability criteria. Concerning the attitude toward IT procurement as an enabler for developing an ERP system, just $21 \%$ of respondents from the utilities sector and $31 \%$ of the manufacturing sector indicated a positive awareness in terms of initiatives that organization adopted. Almost $50 \%$ of the answers from the utilities sector $(48 \%)$ were negative, reflecting the opinion of respondents about the lack of initiatives in terms of developing policies for measuring the environmental performance of their IT suppliers. The major reason for these lower levels of awareness about IT procurement policy in all companies is derived from the fact that companies have inefficient procedures to ensure the purchase, delivery, and installation of IT equipment, in conjunction with a strategic approach of IT infrastructure.

\subsubsection{Awareness of IT Equipment Recycling and Reuse}

This last item of the questionnaire aims to examine the behavior of selected companies concerning IT equipment recycling and reuse. Figure 12 describes the perspective of respondents from economic sectors in terms of positive, negative, and missing answers according to the compliance of companies with the Waste Electrical and Electronic Equipment (WEEE) directive. 


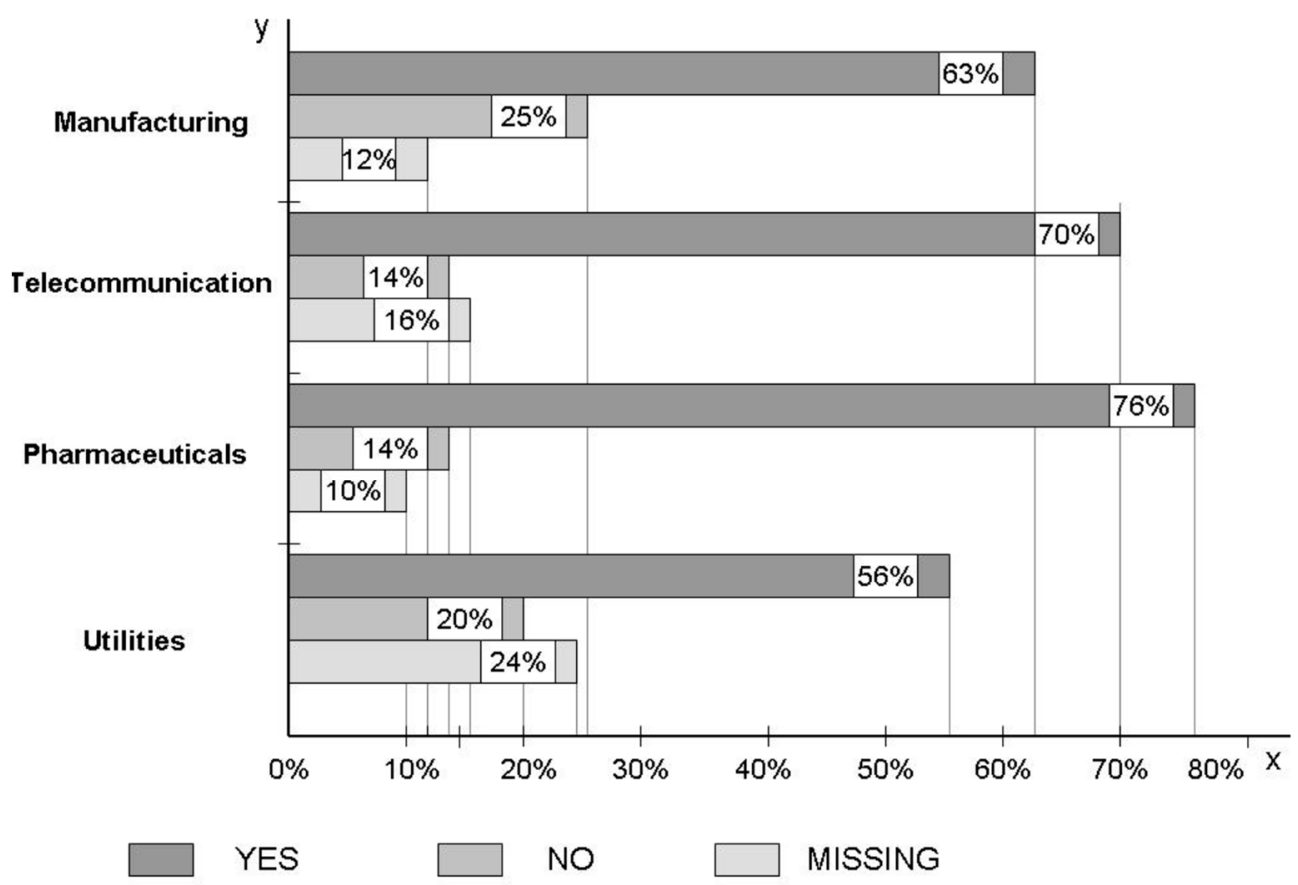

Figure 12. Percentage of compliance to the Waste Electrical and Electronic Equipment (WEEE) directive.

Related to the topic of e-waste, all companies reported a positive attitude toward recycling and reuse measures. The results show that, overall, more than $50 \%$ of respondents agree that there is a great level of awareness about complying with the WEEE directive to decrease the amount of equipment sent to landfills and to diminish e-waste by using responsible recycling vendors. The pharmaceuticals sector pays more attention to recycling solutions $(76 \%)$, whereas those in the utilities sector are less interested (56\%). Additionally, there appears to be a negative opinion about responsible recycling practices in the manufacturing sector $(25 \%)$ and utilities sector $(20 \%)$. This suggests a poor e-waste culture in these sectors and a combination of a lack of environmental responsibilities and regulatory pressures.

The above results are related to each item of the three categories from the questionnaire and allowed us to explore the level of awareness of the companies concerning the integration of ERP systems and advanced green IT solutions. Based on the empirical observational information gained from the questionnaire, we concluded (i.e., regarding the first research question) that green IT practices can be largely incorporated into ERP systems.

The second research question was related to how the incorporation of green IT practices into an ERP system affects the system's sustainability. To verify the conceptual model and the proposed hypothesis, statistical analysis was conducted using the SPSS 21.0 software and an ANOVA F-test. The hypothesis testing involved the construction of the two following statements:

- The null hypothesis: Green IT practices are not positively related to the sustainable development of ERP systems.

- The alternative hypothesis $\left(\mathrm{H}_{1}\right)$ : Green IT practices are positively related to the sustainable development of ERP systems.

In order to explore the relationship between sustainable IT projects and ERP systems we adopted the one-way analysis of variance (ANOVA) to test the direct impact of the independent variable (sustainable IT projects) on each dependent variable (i.e., ERP software sustainability, sustainable management process, and green IT practices) separately.

According to [81], the relationship between two variables can be examined by comparing the mean of the dependent variable between two or more groups within the independent variable. To prepare for the ANOVA test the respondents were divided into four groups (i.e., manufacturing, 
telecommunication, pharmaceuticals, and utilities), based on the mean score and variance of the data set related to the dependent variable. Table 3 presents the summary of the descriptive statistics conducted to observe the distribution of the data.

Table 3. Descriptive statistics.

\begin{tabular}{ccccccccc}
\hline & \multicolumn{7}{c}{ Groups } \\
\cline { 2 - 9 } $\begin{array}{c}\text { Issues in ERP } \\
\text { Systems }\end{array}$ & \multicolumn{2}{c}{ Manufacturing } & \multicolumn{2}{c}{ Telecommunication } & Pharmaceuticals & \multicolumn{2}{c}{ Utilities } \\
\cline { 2 - 9 } & Mean & Variance & Mean & Variance & Mean & Variance & Mean & Variance \\
\hline $\begin{array}{c}\text { Software } \\
\text { sustainability }\end{array}$ & 0.032 & 0.444 & 0.481 & 0.483 & 0.221 & 0.641 & 0.085 & 0.720 \\
\hline $\begin{array}{c}\text { Sustainable } \\
\text { management } \\
\text { process }\end{array}$ & 0.180 & 0.858 & 0.436 & 0.657 & 0.268 & 0.774 & 0.206 & 0.825 \\
\hline $\begin{array}{c}\text { Green IT } \\
\text { practices }\end{array}$ & 0.024 & 0.627 & 0.564 & 0.580 & 0.288 & 0.744 & 0.260 & 0.868 \\
\hline
\end{tabular}

Based on the ANOVA F-test for each economic sector, we attempted to support or reject the null hypothesis depending on the statistical significance of a given set of observations (Table 4).

Table 4. ANOVA test for significant differences between economic sectors based on sustainable IT projects.

\begin{tabular}{|c|c|c|c|c|c|c|}
\hline \multicolumn{7}{|c|}{ ANOVA Test-Manufacturing Sector } \\
\hline Source of Variation & SS & df & MS & F-value & $p$-value & F-critical \\
\hline Between groups & 375.3647059 & 16 & 23.46029 & 37.80513 & 0.00001 & 1.649522 \\
\hline Within groups & 1044.4 & 1683 & 0.620559 & & & \\
\hline Total & 1419.764706 & 1699 & & & & \\
\hline \multicolumn{7}{|c|}{ ANOVA Test-Telecommunication Sector } \\
\hline Source of variation & SS & df & MS & F-value & $p$-value & F-critical \\
\hline Between groups & 96.31059 & 16 & 6.019412 & 10.67971 & 0.00001 & 1.649522 \\
\hline Within groups & 948.59 & 1683 & 0.56363 & & & \\
\hline Total & 1044.901 & 1699 & & & & \\
\hline \multicolumn{7}{|c|}{ ANOVA Test-Pharmaceuticals Sector } \\
\hline Source of variation & SS & df & MS & F-value & $p$-value & F-critical \\
\hline Between groups & 152.9024 & 16 & 9.556397 & 13.42735179 & 0.00001 & 1.649522 \\
\hline Within groups & 1197.81 & 1683 & 0.711711 & & & \\
\hline Total & 1350.712 & 1699 & & & & \\
\hline \multicolumn{7}{|c|}{ ANOVA Test-Utilities Sector } \\
\hline Source of variation & SS & df & MS & F-value & $p$-value & F-critical \\
\hline Between groups & 328.7792 & 16 & 20.5487 & 25.84006 & 0.00001 & 1.649461 \\
\hline Within groups & 1351.885 & 1700 & 0.795227 & & & \\
\hline Total & 1680.664 & 1716 & & & & \\
\hline
\end{tabular}

It was found that the F-value calculated from the data exceeded the critical F-value, for each sector (Table 5). Moreover, the $p$-value of the relationship between the data, which tests the validity of the null hypothesis, is lower than the common alpha level for tests (0.05). Consequently, we reject the null hypothesis and accept the alternative hypothesis as more credible. This means that green IT projects are positively related to the sustainable development of ERP systems. These results also allowed us to draw a conclusion regarding the second research question, i.e., regarding how the incorporation of green IT practices into an ERP system affects the system's sustainability. 
Table 5. Results of the hypothesis testing.

\begin{tabular}{cccc}
\hline Economic Sector & F-Value & $\boldsymbol{p}$-Value & F-Critical \\
\hline Manufacturing & 37.80513 & 0.00001 & 1.649522 \\
Telecommunication & 10.67971 & 0.00001 & 1.649522 \\
Pharmaceuticals & 13.42735179 & 0.00001 & 1.649522 \\
Utilities & 25.84006 & 0.00001 & 1.649461 \\
\hline
\end{tabular}

\section{Conclusions}

Sustainability requires the coordination between sustainable business practices and information technology, which is considered as enabling organizations to improve productivity, reduce costs, and increase competitivity. This paper illustrated how green IT practices can provide an opportunity to increase ERP system value creation through measures that lead to addressing these systems in a greener manner. Our research supports the argument that the integration of sustainability elements into ERP systems is linked to the capacity to innovatively exploit IT, related to both developing software applications and to using these information systems. In this context, we show how green IT practices are able to increase the greenness dimension of an ERP system.

Based on a theoretical framework that proposes criteria for assessing green ERP systems and green IT practices, we administered an online survey to evaluate the current status of companies from Romanian economic sectors related to the relationship between ERP systems and green IT practices. Our main conclusion is that organizational green IT adoption, to create the greenness dimension of an ERP system, is still in the incipient phase. Companies from the manufacturing and utilities sectors are mainly oriented toward inexpensive and easy-to-apply solutions, whereas organizations in the telecommunication and pharmaceuticals sectors reveal a more complex approach to eco-responsible practices. However, the research suggests that although several opportunities exist for undertaking green IT initiatives in order to develop green ERP systems (i.e., sustainable ERP software, sustainable ERP implementing process, energy-efficient computing, server virtualization, responsible IT recycling, etc.), companies are first looking at the operational aspects of ERP systems and less at holistic and integrative solutions for addressing sustainability-related business issues. We think that this situation is generated by certain factors found in all companies.

First, as "going green" is an incremental process that requires top management support, to implement successful projects in environmentally-friendly IT systems, the involvement of the Chief Executive Officer CEO and IT manager is essential. In this regard, our research has emphasized a higher level of awareness among telecommunication and pharmaceuticals companies related to the need for a transversal vision approach to developing green IT solutions and integrating them in the ERP system.

Second, the survey showed that companies adopting green IT practices may face barriers that inhibit the successful implementation of these projects. Over half of the respondents confirmed major weaknesses that limit green computing efforts in their organization, such as inadequate funding, misalignment with strategic approach, no official legislation to promote green IT practices, and low pressure from stakeholders and government. Therefore, the challenge to using eco-responsible IT practices in fostering the green dimension of ERP systems is that companies must start to initiate a comprehensive plan not only addressing the operational level of these systems, but also the integration of sustainability elements in software quality, management aspects of ERP implementation, or business attitudes to going green.

Third, we revealed that the relationship between green IT practices and ERP systems is not relevant, especially due to the low level of environmentally-friendly culture within organizations. The problems faced in addressing ERP systems in a greener manner are the users' attitudes and their motivation to develop an environmental consciousness concerning the opportunities that emerge from green IT solutions. As the research revealed, a holistic approach to greening IT within the analyzed companies is missing. Enterprises are focused on some practices to reduce IT's environmental impact, 
but actions to create eco-responsible behavior among IT users are sporadic and weakly represented within internal formal procedures and best practices addressed by international regulations.

However, this research is only a step toward an approach to green IT alignment with software business solutions. Our sample of companies from four economic sectors provides a limited overview of the relationship between eco-responsible IT practices and ERP systems. Future studies can extend the sample size and the framework of the criteria used to assess the greenness of ERP systems to examine the potential of green IT practices for more environmentally responsible initiatives. There is also an essential limitation of this study related to the qualitative approach of green ERP system criteria and green IT practices. Future research is required to develop a quantitative model to assess the maturity level achieved by an organization in adopting and implementing green IT solutions. This could be done by using the metrics of green IT that are embedded in integrated information systems such as ERP systems. To analyze the type of maturity level (i.e., from an ad hoc, immature process to a mature, disciplined process), the capability maturity model (CMM) can be used [82]. Thus, the organization can identify the best green IT initiatives and practices toward more sustainable development.

Author Contributions: Conceptualization, M.U.; Data curation, D.P., C.S. and I.S.; Investigation, D.P. and I.S.; Methodology, M.U.; Validation, D.P., C.S. and I.S.; Writing—original draft, M.U.

Funding: The research published in this article has been supported by the Romanian Government through CERTRAN project-The Upgrade of the Research Capacity in Economics through Development of a Transdisciplinary Research Infrastructure.

Conflicts of Interest: The authors declare no conflict of interest.

\section{Appendix A}

Table A1. The questionnaire.

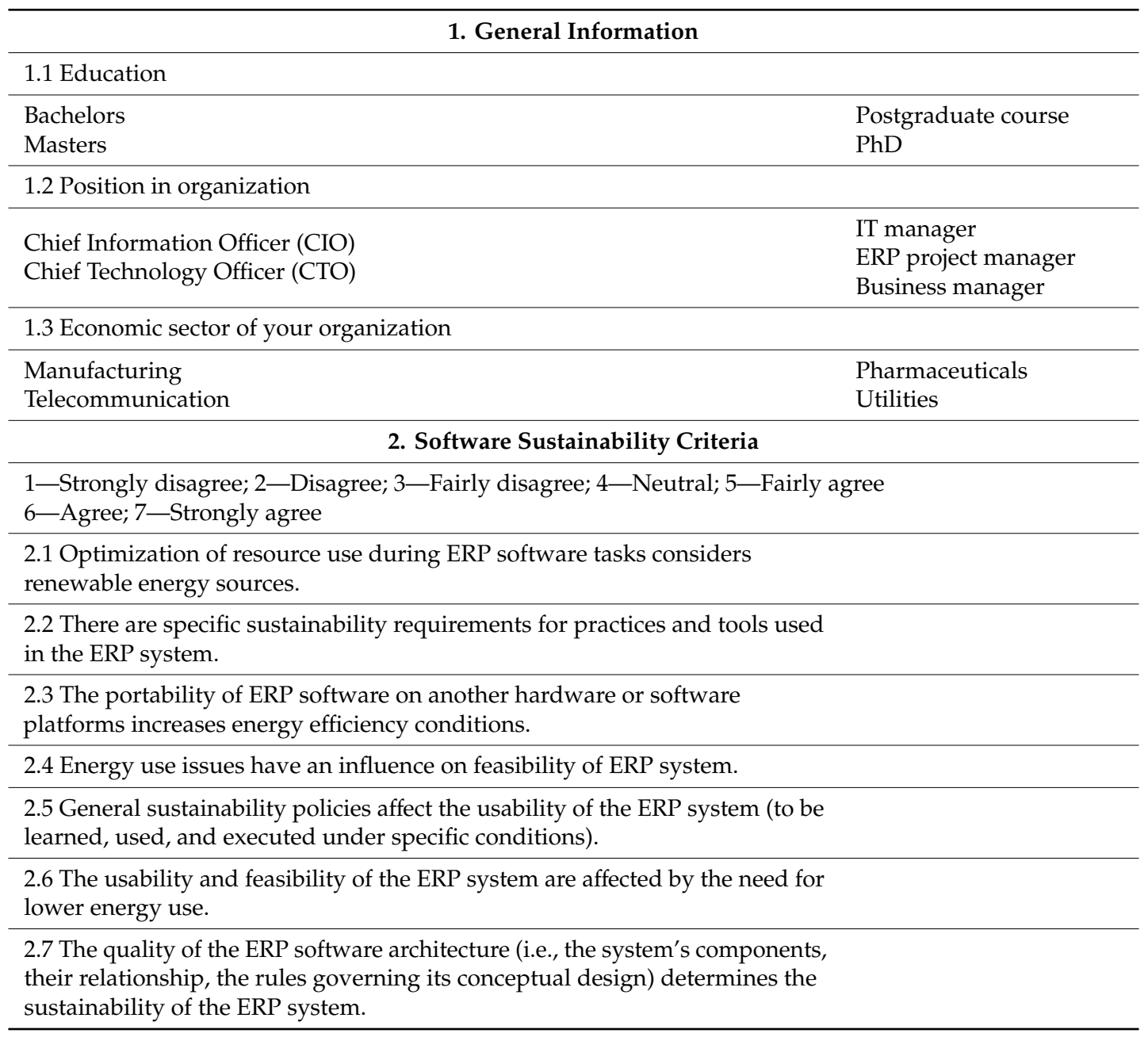


Table A1. Cont.

\section{Sustainable management process to implement ERP system}

1-Strongly disagree; 2-Disagree; 3-Fairly disagree; 4-Neutral; 5-Fairly agree

6-Agree; 7-Strongly agree

3.1 Top management support is a critical success factor when developing sustainability policies for the implementation of an ERP system.

3.2 There is a relationship between environmental IT initiatives and sustainability strategy to fulfill the requirements of the ERP system through eco-responsible IT practices.

3.3 We prefer ERP system vendors that have a good reputation for using IT-based environmental initiatives.

3.4 The organization selects an ERP system vendor that is able to position the products and services in terms of energy consumption and lower costs.

3.5 There is an awareness of users to change their behavior during ERP software tasks (reducing paper, using screensavers, turning off the system when not in use).

\section{Green IT initiatives and practices toward more sustainable ERP system}

1-Strongly disagree; 2-Disagree; 3-Fairly disagree; 4-Neutral; 5-Fairly agree 6-Agree; 7-Strongly agree

4.1 Green IT solutions are the best way to enhance the potential of the ERP system in promoting sustainable business practices by reducing emissions, waste, and costs.

4.2 The problem of addressing ERP system in a greener manner is linked to green IT initiatives adopted at the organization level.

4.3 The main goal of optimizing IT infrastructure related to using an ERP system is to reduce energy consumption and carbon emissions.

4.4 There are initiatives to help motivate employees to adopt environmental practices related to the use of the ERP system (e.g., switching off computer, screensavers, printer consolidation).

4.5 Telecommuting technologies (e.g., teleconferencing, video-conferencing) should be introduced as common practices in using your own ERP system, in order to make it more environmentally friendly.

4.6 To reduce the energy consumption related to the ERP system, the following green IT solutions are used (please specify):

\begin{tabular}{|c|c|}
\hline $\begin{array}{l}\text { Storage consolidation } \\
\text { Server virtualization }\end{array}$ & $\begin{array}{l}\text { Automated Power } \\
\text { Management } \\
\text { Thin Clients }\end{array}$ \\
\hline $\begin{array}{l}4.7 \text { Is your organization aware of whether the ERP system vendor complies } \\
\text { with the software sustainability criteria in the design of ERP applications? }\end{array}$ & $\begin{array}{l}\text { Yes } \\
\text { No } \\
\text { Missing }\end{array}$ \\
\hline $\begin{array}{l}\text { 4.8 Does your organization have an IT procurement policy with the aim of } \\
\text { limiting the environmental impact of purchases through initiatives that help } \\
\text { to make more informed choices when purchasing new equipment? }\end{array}$ & $\begin{array}{l}\text { Yes } \\
\text { No } \\
\text { Missing }\end{array}$ \\
\hline $\begin{array}{l}4.9 \text { Is your organization aware of equipment recycling and reuse, according to } \\
\text { the Waste Electrical and Electronic Equipment (WEEE) regulations? }\end{array}$ & $\begin{array}{l}\text { Yes } \\
\text { No } \\
\text { Missing }\end{array}$ \\
\hline
\end{tabular}




\section{Appendix B}

Table A2. Category 2-Awareness about software sustainability.

\begin{tabular}{|c|c|c|c|c|}
\hline \multirow{2}{*}{$\begin{array}{l}\text { Item } \\
\text { No. }\end{array}$} & \multirow{2}{*}{ Item } & \multicolumn{3}{|c|}{ Level of Agreement (\%) } \\
\hline & & $\mathrm{SD} / \mathrm{D} / \mathrm{FD}$ & $\mathbf{N} \mathbf{F}$ & FA/A/SA \\
\hline \multicolumn{5}{|c|}{ Manufacturing Sector } \\
\hline 2.1 & $\begin{array}{l}\text { Optimization of resource use during ERP software tasks } \\
\text { considers renewable energy sources. }\end{array}$ & 41 & 23 & 36 \\
\hline 2.2 & $\begin{array}{l}\text { There are specific sustainability requirements for practices and } \\
\text { tools used in the ERP system. }\end{array}$ & 57 & 31 & 12 \\
\hline 2.3 & $\begin{array}{l}\text { The portability of ERP software on another hardware or } \\
\text { software platforms increases energy efficiency conditions. }\end{array}$ & 26 & 63 & 11 \\
\hline 2.4 & Energy use issues have an influence on feasibility of ERP system. & 17 & 0 & 83 \\
\hline 2.5 & $\begin{array}{l}\text { General sustainability policies affect the usability of the ERP } \\
\text { system (to be learned, used, and executed under specific } \\
\text { conditions). }\end{array}$ & 79 & 12 & 9 \\
\hline 2.6 & $\begin{array}{l}\text { The usability and feasibility of the ERP system are affected by } \\
\text { the need for lower energy use. }\end{array}$ & 58 & 36 & 6 \\
\hline 2.7 & $\begin{array}{l}\text { The quality of ERP software architecture (i.e., the system's } \\
\text { components, their relationship, the rules governing its } \\
\text { conceptual design) determines the sustainability of the ERP } \\
\text { system. }\end{array}$ & 4 & 0 & 96 \\
\hline Level & agreement score of the economic sector $(\%)$ & 6.84 & 4 & 6.14 \\
\hline \multicolumn{5}{|c|}{ Telecommunication sector } \\
\hline 2.1 & $\begin{array}{l}\text { Optimization of resource use during ERP software tasks } \\
\text { considers renewable energy sources. }\end{array}$ & 24 & 17 & 59 \\
\hline 2.2 & $\begin{array}{l}\text { There are specific sustainability requirements for practices and } \\
\text { tools used in the ERP system. }\end{array}$ & 9 & 35 & 56 \\
\hline 2.3 & $\begin{array}{l}\text { The portability of ERP software on another hardware or } \\
\text { software platforms increases energy efficiency conditions. }\end{array}$ & 0 & 31 & 69 \\
\hline 2.4 & Energy use issues have an influence on feasibility of ERP system. & 3 & 54 & 43 \\
\hline 2.5 & $\begin{array}{l}\text { General sustainability policies affect the usability of the ERP } \\
\text { system (to be learned, used, and executed under specific } \\
\text { conditions). }\end{array}$ & 0 & 21 & 79 \\
\hline 2.6 & $\begin{array}{l}\text { The usability and feasibility of the ERP system are affected by } \\
\text { the need for lower energy use. }\end{array}$ & 48 & 3 & 49 \\
\hline 2.7 & $\begin{array}{l}\text { The quality of ERP software architecture (i.e., the system's } \\
\text { components, their relationship, the rules governing its } \\
\text { conceptual design) determines the sustainability of the ERP } \\
\text { system. }\end{array}$ & 17 & 0 & 83 \\
\hline \multicolumn{2}{|c|}{ Level of agreement score of the economic sector (\%) } & 8.58 & 13.68 & 837.23 \\
\hline
\end{tabular}


Table A2. Cont.

\begin{tabular}{|c|c|c|c|c|}
\hline \multirow{2}{*}{$\begin{array}{l}\text { Item } \\
\text { No. }\end{array}$} & \multirow{2}{*}{ Item } & \multicolumn{3}{|c|}{ Level of Agreement (\%) } \\
\hline & & SD/D/FD & $\mathbf{N}$ & FA/A/SA \\
\hline \multicolumn{5}{|c|}{ Pharmaceuticals sector } \\
\hline 2.1 & $\begin{array}{l}\text { Optimization of resource use during ERP software tasks } \\
\text { considers renewable energy sources. }\end{array}$ & 34 & 12 & 54 \\
\hline 2.2 & $\begin{array}{l}\text { There are specific sustainability requirements for practices and } \\
\text { tools used in the ERP system. }\end{array}$ & 26 & 5 & 69 \\
\hline 2.3 & $\begin{array}{l}\text { The portability of ERP software on another hardware or } \\
\text { software platforms increases energy efficiency conditions. }\end{array}$ & 19 & 29 & 52 \\
\hline 2.4 & Energy use issues have an influence on feasibility of ERP system. & 11 & 72 & 17 \\
\hline 2.5 & $\begin{array}{l}\text { General sustainability policies affect the usability of the ERP } \\
\text { system (to be learned, used, and executed under specific } \\
\text { conditions). }\end{array}$ & 49 & 19 & 32 \\
\hline 2.6 & $\begin{array}{l}\text { The usability and feasibility of the ERP system are affected by } \\
\text { the need for lower energy use. }\end{array}$ & 51 & 7 & 42 \\
\hline 2.7 & $\begin{array}{l}\text { The quality of ERP software architecture (i.e., the system's } \\
\text { components, their relationship, the rules governing its } \\
\text { conceptual design) determines the sustainability of the ERP } \\
\text { system. }\end{array}$ & 5 & 11 & 84 \\
\hline Level & agreement score of the economic sector $(\%)$ & 11.05 & 8.78 & 19.83 \\
\hline \multicolumn{5}{|c|}{ Utilities sector } \\
\hline 2.1 & $\begin{array}{l}\text { Optimization of resource use during ERP software tasks } \\
\text { considers renewable energy sources. }\end{array}$ & 58 & 21 & 21 \\
\hline 2.2 & $\begin{array}{l}\text { There are specific sustainability requirements for practices and } \\
\text { tools used in the ERP system. }\end{array}$ & 83 & 0 & 17 \\
\hline 2.3 & $\begin{array}{l}\text { The portability of ERP software on another hardware or } \\
\text { software platforms increases energy efficiency conditions. }\end{array}$ & 95 & 1 & 4 \\
\hline 2.4 & Energy use issues have an influence on feasibility of ERP system. & 54 & 10 & 36 \\
\hline 2.5 & $\begin{array}{l}\text { General sustainability policies affect the usability of the ERP } \\
\text { system (to be learned, used, and executed under specific } \\
\text { conditions). }\end{array}$ & 38 & 0 & 62 \\
\hline 2.6 & $\begin{array}{l}\text { The usability and feasibility of the ERP system are affected by } \\
\text { the need for lower energy use. }\end{array}$ & 56 & 16 & 28 \\
\hline 2.7 & $\begin{array}{l}\text { The quality of ERP software architecture (i.e., the system's } \\
\text { components, their relationship, the rules governing its } \\
\text { conceptual design) determines the sustainability of the ERP } \\
\text { system. }\end{array}$ & 18 & 8 & 74 \\
\hline \multicolumn{2}{|c|}{ Level of agreement score of the economic sector (\%) } & 13.66 & 1.90 & 8.22 \\
\hline
\end{tabular}

Source: Field Data, 2018-2019. 


\section{Appendix C}

Table A3. Category 3-Awareness of sustainable management process.

\begin{tabular}{|c|c|c|c|c|}
\hline \multirow{2}{*}{$\begin{array}{l}\text { Items } \\
\text { No. }\end{array}$} & \multirow{2}{*}{ Items } & \multicolumn{3}{|c|}{ Level of Agreement (\%) } \\
\hline & & $\mathrm{SD} / \mathrm{D} / \mathrm{FD}$ & $\mathbf{N}$ & FA/A/SA \\
\hline \multicolumn{5}{|c|}{ Manufacturing Sector } \\
\hline 3.1 & $\begin{array}{l}\text { Top management support is a critical success factor when } \\
\text { developing sustainability policies for the implementation of an } \\
\text { ERP system. }\end{array}$ & 29 & 9 & 62 \\
\hline 3.2 & $\begin{array}{l}\text { There is a relationship between environmental IT initiatives and } \\
\text { sustainability strategy to fulfill the requirements of the ERP } \\
\text { system through eco-responsible IT practices. }\end{array}$ & 24 & 2 & 74 \\
\hline 3.3 & $\begin{array}{l}\text { We prefer ERP system vendors that have a good reputation for } \\
\text { using IT-based environmental initiatives. }\end{array}$ & 48 & 5 & 47 \\
\hline 3.4 & $\begin{array}{l}\text { The organization selects an ERP system vendor that is able to } \\
\text { position the products and services in terms of energy } \\
\text { consumption and lower costs. }\end{array}$ & 53 & 5 & 42 \\
\hline 3.5 & $\begin{array}{l}\text { There is an awareness of users to change their behavior during } \\
\text { ERP software tasks (reducing paper, using screensavers, turning } \\
\text { off the system when not in use). }\end{array}$ & 34 & 13 & 53 \\
\hline Level o & agreement score of the economic sector $(\%)$ & 4.56 & 0.82 & 6.75 \\
\hline \multicolumn{5}{|c|}{ Telecommunication sector } \\
\hline 3.1 & $\begin{array}{l}\text { Top management support is a critical success factor when } \\
\text { developing sustainability policies for the implementation of an } \\
\text { ERP system. }\end{array}$ & 13 & 3 & 84 \\
\hline 3.2 & $\begin{array}{l}\text { There is a relationship between environmental IT initiatives and } \\
\text { sustainability strategy to fulfill the requirements of the ERP } \\
\text { system through eco-responsible IT practices. }\end{array}$ & 27 & 0 & 73 \\
\hline 3.3 & $\begin{array}{l}\text { We prefer ERP system vendors that have a good reputation for } \\
\text { using IT-based environmental initiatives. }\end{array}$ & 24 & 21 & 55 \\
\hline 3.4 & $\begin{array}{l}\text { The organization selected an ERP system vendor that is able to } \\
\text { position the products and services in terms of energy } \\
\text { consumption and lower costs. }\end{array}$ & 45 & 14 & 41 \\
\hline 3.5 & $\begin{array}{l}\text { There is an awareness of users to change their behavior during } \\
\text { ERP software tasks (reducing paper, using screensavers, turning } \\
\text { off the system when not in use). }\end{array}$ & 13 & 0 & 87 \\
\hline Level of & agreement score of the economic sector (\%) & 10.37 & 3.23 & 28.9 \\
\hline \multicolumn{5}{|c|}{ Pharmaceuticals sector } \\
\hline 3.1 & $\begin{array}{l}\text { Top management support is a critical success factor when } \\
\text { developing sustainability policies for the implementation of an } \\
\text { ERP system. }\end{array}$ & 17 & 4 & 79 \\
\hline 3.2 & $\begin{array}{l}\text { There is a relationship between environmental IT initiatives and } \\
\text { sustainability strategy to fulfill the requirements of the ERP } \\
\text { system through eco-responsible IT practices. }\end{array}$ & 14 & 2 & 84 \\
\hline 3.3 & $\begin{array}{l}\text { We prefer ERP system vendors that have a good reputation for } \\
\text { using IT-based environmental initiatives. }\end{array}$ & 39 & 0 & 61 \\
\hline
\end{tabular}


Table A3. Cont.

\begin{tabular}{|c|c|c|c|c|}
\hline \multirow{2}{*}{$\begin{array}{l}\text { Items } \\
\text { No. }\end{array}$} & \multirow{2}{*}{ Items } & \multicolumn{3}{|c|}{ Level of Agreement (\%) } \\
\hline & & SD/D/FD & $\mathbf{N}$ & FA/A/SA \\
\hline 3.4 & $\begin{array}{l}\text { The organization selected an ERP system vendor that is able to } \\
\text { position the products and services in terms of energy } \\
\text { consumption and lower costs. }\end{array}$ & 62 & 0 & 38 \\
\hline 3.5 & $\begin{array}{l}\text { There is an awareness of users to change their behavior during } \\
\text { ERP software tasks (reducing paper, using screensavers, turning } \\
\text { off the system when not in use). }\end{array}$ & 42 & 12 & 46 \\
\hline \multicolumn{2}{|c|}{ Level of agreement score of the economic sector $(\%)$} & 9.86 & 1.02 & 17.45 \\
\hline \multicolumn{5}{|c|}{ Utilities sector } \\
\hline 3.1 & $\begin{array}{l}\text { Top management support is a critical success factor when } \\
\text { developing sustainability policies for the implementation of an } \\
\text { ERP system. }\end{array}$ & 23 & 18 & 59 \\
\hline 3.2 & $\begin{array}{l}\text { There is a relationship between environmental IT initiatives and } \\
\text { sustainability strategy to fulfill the requirements of the ERP } \\
\text { system through eco-responsible IT practices. }\end{array}$ & 13 & 24 & 63 \\
\hline 3.3 & $\begin{array}{l}\text { We prefer ERP system vendors that have a good reputation for } \\
\text { using IT-based environmental initiatives. }\end{array}$ & 31 & 0 & 69 \\
\hline 3.4 & $\begin{array}{l}\text { The organization selected an ERP system vendor that is able to } \\
\text { position the products and services in terms of energy } \\
\text { consumption and lower costs. }\end{array}$ & 52 & 0 & 48 \\
\hline 3.5 & $\begin{array}{l}\text { There is an awareness of users to change their behavior during } \\
\text { ERP software tasks (reducing paper, using screensavers, turning } \\
\text { off the system when not in use). }\end{array}$ & 47 & 33 & 20 \\
\hline \multicolumn{2}{|c|}{ Level of agreement score of the economic sector (\%) } & 4.03 & 1.82 & 6.29 \\
\hline
\end{tabular}

Source: Field Data, 2018-2019.

\section{Appendix D}

Table A4. Category 4-Awareness about green IT initiatives and practices.

\begin{tabular}{|c|c|c|c|c|}
\hline \multirow{2}{*}{$\begin{array}{c}\text { Item } \\
\text { No. }\end{array}$} & \multirow{2}{*}{ Item } & \multicolumn{3}{|c|}{ Level of Agreement (\%) } \\
\hline & & $\mathrm{SD} / \mathrm{D} / \mathrm{FD}$ & $\mathbf{N}$ & FA/A/SA \\
\hline \multicolumn{5}{|c|}{ Manufacturing Sector } \\
\hline 4.1 & $\begin{array}{l}\text { Green IT solutions are the best way to enhance the potential of } \\
\text { the ERP system in promoting sustainable business practices by } \\
\text { reducing emissions, waste, and costs. }\end{array}$ & 12 & 9 & 79 \\
\hline 4.2 & $\begin{array}{l}\text { The problem of addressing ERP system in a greener manner is } \\
\text { linked to green IT initiatives adopted at the organization level. }\end{array}$ & 39 & 21 & 40 \\
\hline 4.3 & $\begin{array}{l}\text { The main goal of optimizing IT infrastructure related to using } \\
\text { an ERP system is to reduce energy consumption and carbon } \\
\text { emissions. }\end{array}$ & 42 & 13 & 45 \\
\hline 4.4 & $\begin{array}{l}\text { There are initiatives to help motivate employees to adopt } \\
\text { environmental practices related to the use of ERP system (e.g., } \\
\text { switching off computer, screensavers, printer consolidation). }\end{array}$ & 63 & 27 & 10 \\
\hline 4.5 & $\begin{array}{l}\text { Telecommuting technologies (e.g., teleconferencing, } \\
\text { video-conferencing) should be introduced as common practices } \\
\text { in using your own ERP system, in order to make it more } \\
\text { environmentally friendly. }\end{array}$ & 74 & 11 & 15 \\
\hline \multicolumn{2}{|c|}{ Level of agreement score of the economic sector $(\%)$} & 5.58 & 1.96 & 4.59 \\
\hline
\end{tabular}


Table A4. Cont.

\begin{tabular}{|c|c|c|c|c|}
\hline \multirow{2}{*}{$\begin{array}{l}\text { Item } \\
\text { No. }\end{array}$} & \multirow{2}{*}{ Item } & \multicolumn{3}{|c|}{ Level of Agreement (\%) } \\
\hline & & SD/D/FD & $\mathbf{N}$ & FA/A/SA \\
\hline \multicolumn{5}{|c|}{ Telecommunication sector } \\
\hline 4.1 & $\begin{array}{l}\text { Green IT solutions are the best way to enhance the potential of } \\
\text { the ERP system in promoting sustainable business practices by } \\
\text { reducing emissions, waste, and costs. }\end{array}$ & 24 & 8 & 68 \\
\hline 4.2 & $\begin{array}{l}\text { The problem of addressing ERP system in a greener manner is } \\
\text { linked to green IT initiatives adopted at the organization level. }\end{array}$ & 19 & 17 & 64 \\
\hline 4.3 & $\begin{array}{l}\text { The main goal of optimizing IT infrastructure related to using } \\
\text { an ERP system is to reduce energy consumption and carbon } \\
\text { emissions. }\end{array}$ & 14 & 5 & 81 \\
\hline 4.4 & $\begin{array}{l}\text { There are initiatives to help motivate employees to adopt } \\
\text { environmental practices related to the use of the ERP system } \\
\text { (e.g., switching off computer, screensavers, printer } \\
\text { consolidation). }\end{array}$ & 21 & 10 & 69 \\
\hline 4.5 & $\begin{array}{l}\text { Telecommuting technologies (e.g., teleconferencing, } \\
\text { video-conferencing) should be introduced as common practices } \\
\text { in using your own ERP system, in order to make it more } \\
\text { environmentally friendly. }\end{array}$ & 9 & 4 & 87 \\
\hline Level o & agreement score of the economic sector $(\%)$ & 7.39 & 3.74 & 31.36 \\
\hline \multicolumn{5}{|c|}{ Pharmaceuticals sector } \\
\hline 4.1 & $\begin{array}{l}\text { Green IT solutions are the best way to enhance the potential of } \\
\text { the ERP system in promoting sustainable business practices by } \\
\text { reducing emissions, waste, and costs. }\end{array}$ & 36 & 19 & 45 \\
\hline 4.2 & $\begin{array}{l}\text { The problem of addressing ERP system in a greener manner is } \\
\text { linked to green IT initiatives adopted at the organization level. }\end{array}$ & 19 & 6 & 75 \\
\hline 4.3 & $\begin{array}{l}\text { The main goal of optimizing IT infrastructure related to using } \\
\text { an ERP system is to reduce energy consumption and carbon } \\
\text { emissions. }\end{array}$ & 31 & 0 & 69 \\
\hline 4.4 & $\begin{array}{l}\text { There are initiatives to help motivate employees to adopt } \\
\text { environmental practices related to the use of the ERP system } \\
\text { (e.g., switching off computer, screensavers, printer } \\
\text { consolidation). }\end{array}$ & 16 & 25 & 59 \\
\hline 4.5 & $\begin{array}{l}\text { Telecommuting technologies (e.g., teleconferencing, } \\
\text { video-conferencing) should be introduced as common practices } \\
\text { in using your own ERP system, in order to make it more } \\
\text { environmentally friendly. }\end{array}$ & 43 & 16 & 41 \\
\hline Level o & agreement score of the economic sector (\%) & 8.21 & 3.74 & 16.37 \\
\hline \multicolumn{5}{|c|}{ Utilities sector } \\
\hline 4.1 & $\begin{array}{l}\text { Green IT solutions are the best way to enhance the potential of } \\
\text { the ERP system in promoting sustainable business practices by } \\
\text { reducing emissions, waste, and costs. }\end{array}$ & 23 & 20 & 57 \\
\hline 4.2 & $\begin{array}{l}\text { The problem of addressing ERP system in a greener manner is } \\
\text { linked to green IT initiatives adopted at the organization level. }\end{array}$ & 41 & 2 & 57 \\
\hline 4.3 & $\begin{array}{l}\text { The main goal of optimizing IT infrastructure related to using } \\
\text { an ERP system is to reduce energy consumption and carbon } \\
\text { emissions. }\end{array}$ & 16 & 15 & 69 \\
\hline
\end{tabular}


Table A4. Cont.

\begin{tabular}{clcc}
\hline \multirow{2}{*}{$\begin{array}{c}\text { Item } \\
\text { No. }\end{array}$} & \multicolumn{1}{c}{ Item } & \multicolumn{2}{c}{ Level of Agreement (\%) } \\
\cline { 3 - 5 } 4.4 & SD/D/FD & N & FA/A/SA \\
\hline $\begin{array}{l}\text { There are initiatives to help motivate employees to adopt } \\
\text { environmental practices related to the use of the ERP system } \\
\text { (e.g., switching off computer, screensavers, printer } \\
\text { consolidation). }\end{array}$ & 67 & 5 & 28 \\
\hline $\begin{array}{l}\text { Telecommuting technologies (e.g., teleconferencing, } \\
\text { video-conferencing) should be introduced as common practices } \\
\text { in using your own ERP system, in order to make it more } \\
\text { environmentally friendly. }\end{array}$ & 13 & 26 & 61 \\
\hline Level of agreement score of the economic sector (\%) & $\mathbf{5 . 4 4}$ & $\mathbf{2 . 3 1}$ & $\mathbf{9 . 2 4}$ \\
\hline
\end{tabular}

Source: Field Data, 2018-2019.

\section{References}

1. Purvis, B.; Mao, Y.; Robinson, D. Three Pillars of Sustainability: In Search of Conceptual Origins. Sustain. Sci. 2019, 14, 681-695. [CrossRef]

2. Boyer, R.H.W.; Peterson, N.D.; Arora, P.; Caldwell, K. Five Approaches to Social Sustainability and an Integrated Way Forward. Sustainability 2016, 8, 878. [CrossRef]

3. Bartlett, R.P., III. Shareholder Wealth Maximization as Means to an End. Berkeley Law Scholarship Repository. Seattle Univ. Law Rev. 2014, 38, 255.

4. Ajami, S.; Arab-Chadegani, R. The effects of applying information technology on job empowerment dimensions. J. Educ. Health Promot. 2014, 3. [CrossRef]

5. Simba, D.O.; Mwangu, M. Application of ICT in strengthening health information systems in developing countries in the wake of globalization. Afr. Health Sci. 2004, 4, 194-198. [PubMed]

6. Vom Brocke, J.; Seidel, S.; Los, P.; Watson, R. Green IS-Information Systems for Environmental Sustainability. Bus. Inf. Syst. Eng. 2013, 4, 295-297. [CrossRef]

7. Brooks, S.; Wang, X.; Sarker, S. Unpacking Green Is: A Review of the Existing Literature and Directions for the Future. In Green Business Process Management; vom Brocke, J., Seidel, S., Recker, J., Eds.; Springer: Berlin, Germany, 2012; pp. 15-37.

8. Butler, T. Compliance with institutional imperatives on environmental sustainability: Building theory on the role of Green IS. J. Strateg. Inf. Syst. 2011, 20, 6-26. [CrossRef]

9. Ahmed, M.D.; Sundaram, D. Sustainable Business Transformation. In Proceedings of the AMCIS, Detroit, MI, USA, 4-8 August 2011. Available online: https://aisel.aisnet.org/amcis2011_submissions/356 (accessed on 16 March 2019).

10. Sarkar, A.N. Promoting Eco-innovations to Leverage Sustainable Development of Eco-industry and Green Growth. Eur. J. Sustain. Dev. 2013, 2, 171-224. Available online: https://www.ecsdev.org/images/V2N1/ sarkar\%20171-224.pdf (accessed on 16 March 2019).

11. Venhoeven, L.A.; Bolderdjik, J.W.; Steg, L. Why Acting Environmentally-Friendly Feels Good: Exploring the Role of Self Image. Front. Psychol. 2016, 7, 1846. [CrossRef]

12. Needhidasan, S.; Samuel, M.; Chidambaram, R. Electronic waste-an emerging threat to the environment of urban India. J. Environ. Health Sci. Eng. 2014, 12, 36. [CrossRef]

13. Alhorr, Y.; Eliskandarani, E.; Elsarrag, E. Approaches to Reducing Carbon Dioxide Emissions in The Built Enviroenment: Low Carbon Cities. Int. J. Sustain. Built Environ. 2014, 3, 167-178. [CrossRef]

14. Erickson, L.E. Reducing greenhouse gas emissions and improving air quality: Two global challenges. Environ. Prog. Sustain. Energy 2017, 36, 982-988. [CrossRef] [PubMed]

15. Teehan, P.; Kandlikar, M. Comparing Embodied Greenhouse Gas Emissions of Modern Computing and Electronics Products. Environ. Sci. Technol. 2013, 47, 3997-4003. [CrossRef]

16. von Gadow, K. Managing Forest Ecosystems: The Challenge of Climate Change; Bravo, F., LeMay, V., Jandl, R., Eds.; Springer: Dordrecht, The Netherlands, 2008; Volume 3-4, pp. 385-387. 
17. Hilty, L.; Bieser, J. Opportunities and Risks of Digitalization for Climate Protection in Switzerland. University of Zurich, Informatics and Sustainability Research Group, October 2017. Available online: https://www.doi. org/10.5167/uzh-141128 (accessed on 19 February 2019).

18. European Commission. A Clean Planet for all. A European Strategic Long-Term Vision for a Prosperous, Modern, Competitive and Climate Neutral Economy; European Commission: Brussels, Belgium, 2018. Available online: https://eur-lex.europa.eu/legal-content/EN/TXT/PDF/?uri=CELEX:52018DC0773\&from=EN (accessed on 19 February 2019).

19. World Economic Forum. Why Energy Efficiency is Key to Sustainable Development; World Economic Forum, 2015. Available online: https://www.weforum.org/agenda/2015/06/why-energy-efficiency-is-key-to-sustainabledevelopment/ (accessed on 27 February 2019).

20. Ranjit, B.; Xin, R.L. Green IT adoption: A process management approach. Int. J. Account. Inf. Manag. 2012, 20,63-77. [CrossRef]

21. Murugesan, S. Harnessing Green IT: Principles and Practices. IEEE It Prof. Rev. 2008, 1, 24-33. [CrossRef]

22. Murugesan, S. On Harnessing Green IT and Cloud Computing. SetLabs Brief. Infosys Spec. Issue Green IT 2011, 9, 39-49. Available online: http://infosys.com/infosys-labs/publications/setlabs-briefings/Pages/green-IT.aspx (accessed on 27 June 2018).

23. Molla, A. GITAM: A model for the adoption of Green IT. In Proceedings of the 19th ACIS, Christchurch, New Zealand, 3-5 December 2008; pp. 658-668. Available online: https://aisel.aisnet.org/acis2008/64 (accessed on 18 March 2019).

24. Philipson, G. A Green ICT Framework: Understanding and Measuring Green ICT; Connection Research Services Pty Ltd. (ABN 47092657 513): St. Leonards, Australia, 2010.

25. Chofreh, A.G.; Goni, F.A.; Klemes, J.J. A roadmap for Sustainable Enterprise Resource Planning Systems Implementation (part III). J. Clean. Prod. 2018, 174, 1325-1337. [CrossRef]

26. Al-Nakib Noofal, A.M.M.; Hu, W. Using Management Information Systems (MIS) to Boost Corporate Performance. Int. J. Manag. Sci. Bus. Adm. 2015, 1, 55-61.

27. Monk, E.; Wagner, B. Concepts in Enterprise Resource Planning, 4th ed.; Cengage Learning: Boston, MA, USA, 2012; pp. 16-27.

28. Aloini, D.; Dulmin, R.; Mininno, V. Risk Management in ERP Project Introduction: Review of the Literature. Inf. Manag. 2007, 44, 547-567. [CrossRef]

29. Cardoso, J.; Bostrom, R.P.; Sheth, A. Workflow Management Systems and ERP Systems: Differences, Commonalities, and Applications. Inf. Technol. Manag. 2004, 5, 319-338. [CrossRef]

30. Pohludka, M.; Stverkova, H.; Slusarczyk, B. Implementation and Unification of the ERP System in a Global Company as a Strategic Decision for Sustainable Entrepreneurship. Sustainability 2018, 10, 2916. [CrossRef]

31. Ibrahim, I.; Jamil, N.A.; Halin, I.A. Green Enterprise Resource Planning and Green Logistics Performance. SIJ Trans. Ind. Financ. Bus. Manag. (IFBM) 2018, 6, 1-6, eISSN: 2321-242X. [CrossRef]

32. Staniškis, J.K.; Arbačiauskas, V. Sustainability Performance Indicators for Industrial Enterprise Management. Environ. Res. Eng. Manag. 2009, 2, 42-50.

33. Hasan, M.S.; Ebrahim, Z.; Wan Mahmood, W.H.; Ab Rahman, M.N. Sustainable-ERP System: A Preliminary Study on Sustainability Indicators. J. Adv. Manuf. Technol. 2017, 11, 61-74, eISSN: 2289-8107.

34. Chofreh, A.G.; Goni, F.A.; Shaharoun, A.M.; Ismail, S.; Klemeš, J.J. Sustainable enterprise resource planning: Imperatives and research directions. J. Clean. Prod. 2014, 71, 139-147. [CrossRef]

35. Boltena, A.S.; Rapp, B.; Solsbach, A.; G\&ómez, J.M. Towards Green ERP Systems: The selection driven perspective. In Proceedings of the 28th EnviroInfo 2014 Conference, Oldenburg, Germany, 10-12 September 2014; pp. 421-429. Available online: https://pdfs.semanticscholar.org/0a34/ 9983ad1db6dd75669d4235ecf53763a6120b.pdf?ga=2.91118810.1934685862.1551426927-1461380949. 1551426927 (accessed on 17 March 2019).

36. Butler, T.; Daly, M. Environmental Responsibility and Green IT: An Institutional Perspective. In Proceedings of the ECIS 2008, Suzhou, China, 13-17 December 2008; p. 10. Available online: https://aisel.aisnet.org/ ecis2008/10 (accessed on 19 March 2019).

37. Frost, G.; Jones, S.; Lee, P. The Collection, Integration and Reporting of Sustainability Information within an Organization: State of Practice; University of Sidney: Sidney, Australia; CPA Australia: Sidney, Australia, 2012. Available online: https://www.cpaaustralia.com.au/media/corporate/allfiles/document/professionalresources/sustainability/collection-integration-reporting-sustainability.pdf?la=en (accessed on 3 March 2019). 
38. Rajan, C.A.; Baral, R. Adoption of ERP system: An empirical study of factors influencing the usage of ERP and its impact on end user. IIMB Manag. Rev. 2015, 27, 105-117. [CrossRef]

39. Weng,H.H.R.; Chen, J.S.; Chen, P.C. Effects of Green Innovation on Environmental and Corporate Performance: A Stakeholder Perspective. Sustainability 2015, 7, 4997-5026. [CrossRef]

40. Chofreh, A.G.; Goni, F.A.; Klemes, J.J. Steps towards the Implementation of Sustainable Enterprise Resource Planning Systems. Chem. Eng. Trans. 2018, 70, 283-288. [CrossRef]

41. Chofreh, A.G.; Goni, F.A.; Malik, M.N.; Khan, H.H.; Klemeš, J.J. Evaluation of the Sustainable Enterprise Resource Planning Implementation Steps. Chem. Eng. Trans. 2019, 72, 445-450. [CrossRef]

42. Poon, P.L.; Yu, Y.T. Investigating ERP Systems Procurement Practice: Hong Kong \& Australian Experiences. Inf. Softw. Technol. 2010, 52, 1011-1022. [CrossRef]

43. Dao, V.T.; Langella, I.; Carbo, J. From Green to Sustainability: Information Technology and an Integrated Sustainability Framework. J. Strateg. Inf. Syst. 2011, 20, 63-79. [CrossRef]

44. Velte, T.; Velte, A.; Elsenpeter, R. Green IT-Reduce Your Information System's Environmental Impact While Adding to the Bottom Line, 1st ed.; McGraw-Hill Education: New York, NY, USA, 2008; pp. 133-146.

45. Molla, A.; Abareshi, A. Green IT Adoption: A Motivational Perspective. In Proceedings of the PACIS, Brisbane, Australia, 7-11 July 2011. Available online: https:/aisel.aisnet.org/pacis2011/137/ (accessed on 16 March 2019).

46. Molla, A. The Reach and Richness of Green IT: A Principal Component Analysis. In Proceedings of the 20th Australasian Conference on Information Systems (ACIS), Melbourne, Australia, 2-4 December 2009; pp. 754-764.

47. Hasan, H. Unordered Business Processes, Sustainability and Green IS. In Green Business Process Management; Vom Brocke, J., Seidel, S., Recker, J., Eds.; Springer: Berlin/Heidelberg, Germany, 2012; pp. 39-58.

48. Zarrella, E. Sustainable IT-The Case for Strategic Leadership; KPMG: Zürich, Switzerland, 2008. Available online: http://www.greenprof.org/wp-content/uploads/2010/05/Sustainable-IT-The-case-forstrategic-leadership.pdf (accessed on 19 February 2019).

49. Harmon, R.R.; Auseklis, N. Sustainable IT services: Assessing the Impact of Green Computing Practices. In Proceedings of the PICMET 2009, Portland, OR, USA, 2-6 August 2009; pp. 1707-1717. [CrossRef]

50. Watson, R.T.; Boudreau, M.C.; Chen, A.J. Information Systems and Environmentally Sustainable Development: Energy Informatics and New Directions for the IS Community. MIS Q. 2010, 34, 23-38. [CrossRef]

51. Sen, S.; Bhattacharya, C.B.; Korschun, D. The Role of Corporate Social Responsibility in Strengthening Multiple Stakeholder Relationships. J. Acad. Mark. Sci. 2009, 34, 158-166. [CrossRef]

52. Naumann, S.; Dick, M.; Kern, E.; Johann, T. The GREENSOFT Model: A Reference Model for Green and Sustainable Software and its Engineering. Sustain. Comput. Inform. Syst. 2011, 1, 294-304. [CrossRef]

53. Albertao, F.; Xiao, J.; Tian, C.; Lu, Y.; Zhang, K.Q.; Liu, C. Measuring the Sustainability Performance of Software Projects. In Proceedings of the IEEE 7th International Conference on e-Business Engineering (ICEBE 2010), Shanghai, China, 20-22 November 2010; IEEE Computer Society: Washington, DC, USA, 2010; pp. 369-373. [CrossRef]

54. Mahmoud, S.S.; Ahmad, I. A Green Model for Sustainable Software Engineering. Int. J. Softw. Eng. Its Appl. 2013, 7, 55-74.

55. Kogetsidis, H.; Kokkinaki, A.; Soteriou, V. Enterprise Resource Planning Implementation in the Retail Sector: A Case Study on the Effects of the Implementation of an ERP System in Cyprus. J. Int. Bus. Entrep. Dev. 2008, 3, 270-283. [CrossRef]

56. Lubin, D.A.; Esty, D.C. The sustainability imperative. Harv. Bus. Rev. 2010, 88, 42-50.

57. Sahran, S.; Goni, F.A.; Mukhtar, M. ERP Implementation Challenges in Small and Medium Enterprise: A Framework and Case Study. Adv. Mater. Res. 2010, 139-141, 1636-1639. [CrossRef]

58. Somers, T.M.; Nelson, K. The impact of CSFs across the stages of ERP implementation. In Proceedings of the 34th Annual Hawaii International Conference on System Sciences, Maui, HI, USA, 6 January 2001. [CrossRef]

59. Umble, E.; Haft, R.; Umble, M. Enterprise Resource Planning: Implementation procedures and critical success factors. Eur. J. Oper. Res. 2003, 146, 241-257. [CrossRef]

60. Kumar, V.; Maheshwari, B.; Kumar, U. An investigation of critical management issues in ERP implementation: Empirical evidence from Canadian organizations. Technovation 2003, 23, 793-807. [CrossRef]

61. Nah, F.H.F.; Delgado, S. Critical Success Factors for Enterprise Resource Planning Implementation and Upgrade. J. Comput. Inf. Syst. 2006, 46, 99. [CrossRef] 
62. Wei, C.C.; Chien, C.F.; Wang, M.J.J. An AHP-based approach to ERP system selection. Int. J. Prod. Res. 2005, 96, 47-62. [CrossRef]

63. Ayaug, Z.; Özdemir, R. An intelligent approach to ERP software selection through fuzzy ANP. Int. J. Prod. Res. 2007, 45, 2169-2194. [CrossRef]

64. Kumar, V.; Maheshwari, B.; Kumar, U. Enterprise resource planning systems adoption process: A survey of Canadian organizations. Int. J. Prod. Res. 2002, 40, 509-523. [CrossRef]

65. Molla, A.; Cooper, V.A.; Pittayachawan, S. IT and Eco-sustainability: Developing and validating a Green IT readiness model. In Proceedings of the ICIS 2009, Phoenix, AZ, USA, 15-18 December 2009; p. 141. Available online: http://www.pacis-net.org/file/2009/2373.pdf (accessed on 15 May 2019).

66. Bose, R.; Luo, X. Integrative framework for assessing firms' potential to undertake Green IT initiatives via virtualization-A theoretical perspective. J. Strateg. Inf. Syst. 2011, 20, 38-54. [CrossRef]

67. Desai, B.M.; Bhatia, V. Green IT Maturity Model: How does your Organization Stack Up? SetLabs Brief. Infosys 2011, 9, 49-57.

68. Foogooa, R.; Bokhoree, C.; Dookhitram, K. Green ICT Maturity Models-Towards a general approach. In Proceedings of the International Conference on Computing, Communication and Security (ICCCS), Pointe aux Piments, Mauritius, 4-5 December 2015. [CrossRef]

69. Deng, Q.; Ji, S. Organizational Green IT Adoption: Concept and Evidence. Sustainability 2015, 7, 16737-16755. [CrossRef]

70. Molla, A.; Cooper, V.; Pittayachawan, S. The Green IT Readiness (G-Readiness) of Organizations: An Exploratory Analysis of a Construct and Instrument. Commun. Assoc. Inf. Syst. 2011, 29, 67-96. [CrossRef]

71. Barroso, L.A.; Hölze, U. The Case for Energy-Proportional Computing. IEEE Comput. Soc. 2007, 40, 33-37. [CrossRef]

72. Enterprise Management Associates (EMA), The True Value of Green IT-An EMA Research Report. 2008. Available online: http://ondemand.kaseya.hk/download/en-us/white_papers/EMA.True.Value.Green. Computing.pdf (accessed on 16 March 2019).

73. Info-Tech Research Group. Green IT: Why Mid-Size Companies are Investing Now. Toronto, Canada: International Organization for Standardization: Software Engineering. 2009. Available online: https: //www-03.ibm.com/press/attachments/GreenIT-final-Mar.4.pdf (accessed on 17 March 2019).

74. Uddin, M.; Rahman, A.A. Energy efficiency and low carbon enabler green IT framework for data centers considering green metrics. Renew. Sustain. Energy Rev. 2012, 16, 4078-4094. [CrossRef]

75. Kiruthiga, P.; Vinoth Kumar, T. Green Computing-An ecofriendly approach for energy efficiency and minimizing e-waste. Int. J. Eng. Res. 2014, 3, 356-359. [CrossRef]

76. Ryan, E.J. Building Sustainable IT. Cut. IT J. 2008, 21, 6-12.

77. Government of Romania. National Strategy for Competitiveness 2015-2020, 2015. Available online: https://lege5. ro/MonitorOficial/monge3tknjrhe/monitorul-oficial-partea-i-nr-756-09-10-2015 (accessed on 27 May 2019).

78. Government of Romania. National Strategy of Research, Development, and Innovation 2014-2020, 2014. Available online: https://www.edu.ro/sites/default/files/_fi\%C8\%99iere/Minister/2016/strategii/strategia-cdi2020_-proiect-hg.pdf (accessed on 27 May 2019).

79. Valoria Business Solutions, Ltd. Study on Managers' Perception of the Impact of Digitalization on Romanian Companies. 2017. Available online: https://valoria.ro/wp-content/uploads/2017/12/Sample_Barometruldigitalizarii-2017_RO.pdf (accessed on 27 May 2019).

80. Mueller, B.; Urbach, N. Understanding the Why, What, and How of Theories in IS Research. Commun. Assoc. Inf. Syst. 2017, 41, 349-388. [CrossRef]

81. Venkatesh, V.; Brown, S.; Bala, H. Bridging the qualitative-quantitative divide: Guidelines for conducting mixed methods research in information systems. MIS Q. 2013, 37, 21-54. [CrossRef]

82. Paulk, M.C. The Evolution of the SEFs Capability Maturity Model for Software. Pilot Issue. Softw. Process: Improv. Pract. 1995, 1, 3-15.

(C) 2019 by the authors. Licensee MDPI, Basel, Switzerland. This article is an open access article distributed under the terms and conditions of the Creative Commons Attribution (CC BY) license (http://creativecommons.org/licenses/by/4.0/). 